PNL-8231

UC-\$02

\title{
Evaluation of New Concepts for In Situ Vitrification: Power System, Melt Insulation, and Off-Gas Containment
}

\author{
1. Luey \\ T. D. Powell \\ W. O. Heath \\ R. L. Richardson
}

July 1992

Prepared for the U.S. Department of Energy under Contract DE-AC06-76RLO 1830

Pacific Northwest Laboratory

Operated for the U.S. Department of Energy

by Battelle Memorial Institute

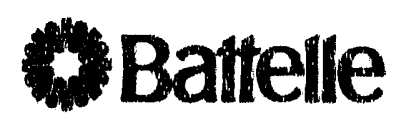




\title{
DISCLAIMER
}

This report was prepared as an account of work sponsored by an agency of the United States Government. Neither the United States Government nor any agency thereof, nor Battelle Memorial Institute, nor any of their employees, makes any warranty, expressed or implied, or assumes any legal liability or responsibility for the accuracy, completeness, or usefulness of any information, apparatus, product, or process disclosed, or represents that its use would not infringe privately owned rights. Reference herein to any specific commercial product, process, or service by trade name, trademark, manufacturer, or otherwise does not necessarily constitute or imply its endorsement, recornmendation, or favoring by the United States Government or any agency thereof, or Battelle Menorial Institute. The views and opinions of authors expressed herein do not necessarily state or reflect those of the United States Government or any agency thereof.

\author{
PACIFIC NORTHWEST LABORATORY \\ operated by \\ BATTELLLE MEMORIAL INSTITUTE \\ for the \\ UNITED STATES DEPARTMENT OF ENERGY \\ under Contract DE-ACO6-76RLO 1830
}

Printed in the United States of America

Available to DOE and DOE contractors from the

Difice of Scientific and Technical information, P.O. Box 62, Oak Ridge, TN 37831; prices available from (615) 576-8401. FTS 626-8401.

Available to the public from the National Technical Information Servict,

U.S. Department of Commerce, 52B5 Port Royal Rd., Springfield, VA 22161. 
PNL -8231

DE92 019799

Evaluation of New Concepts for In Situ Vitrification:

Power System. Melt Insulation, and Off-Gas Containment

J. Luey

T. D. Powell

W. O. Heath

R. L. Richardson

JuTy 1992

Prepared for

the U.S. Department of Energy

under Contract DE-ACO6-76RLO 1830

Pacific Northwest Laboratory

Richland. Washington

\section{MASTER}


New concepts for the in situ vitrification (ISV) technology were successfully demonstrated in September 1991 during the operational acceptance test (OAT) of PNL's upgraded engineering-scale unit. These concepts are developments in power use, melt surface insulation, and off-gas containment. and they result in the following:

\footnotetext{
- a three-phase, three-electrode power system. The direct use of three-phase power, rather than converting three-phase to fourphase via a Scott connected transformer. will result in better compatibility with three-phase utilities and increased control of ISV power input.

- a water spray system. Laboratory-and field-scale experience in processing buried sealed containers indicates these containers can potentially cause transient events in the off-gas containment hood that lead to loss of containment. The water spray system is a proposed means of mitigating the transient events in the off-gas hood (this concept for pressure reduction has been used in the nuclear industry).

- an insulative ceramic bead layer. The current method of insulating an ISV meit surface does not survive the duration of an ISV test. Ceramic beads applied to the melt surface may provide long. term insulation by floating on the melt surface. Benefits include the prevention of a rising cold cap and promotion of melt subsidence.

- a positive pressure electrode seals. During transient events in the off-gas containment hood, the electrode insertion points potentially permit the exit of untreated gases and particulate. The positive pressure electrode seals would eliminate this potential for exit by providing a pressurized gas zone that would be impenetrable by gases and particulate.
}

The OAT was performed in three powered operational stages using the three-phase, three-electrode power supply system. During start-up of the first powered stage, voltage from the $75 \mathrm{kVA}$ transformer was limited, but this problem was remedied during the second and third powered stages by circumventing the transformer during start-up. After preliminary testing of equipment and operational controls for the three-phase power system. smooth and reliable power operations were achieved during the third powered stage. The third powered stage required $810 \mathrm{kWh}$ of energy and produced an ISV block weighing $830 \mathrm{~kg}$. demonstrating that a three-phase, three-electrode power system is a viable alternative to the currently used scott connected transformer system. 
During the second and third powered operational stages, the water spray system was tested. Upon initiation of the water spray system. the conditions in the off-gas containment hood showed an increase in hood vacuum and a decrease in the off-gas exit temperature. The responsus in the off-gas hood were within the range predicted by supporting calculations. Transient events were not simulated for the engineering-scale OAT, but the results from the water spray trials indicate great potential for the use of this system to mitigate pressure and temperature events in the hood.

Lightweight ceramic beads were used to insulate the predicted melt zone during each of the three powered operational stages. Based on observations of the three stages, the beads remained floating on the melt surface. In addition, the region covered by the beads readily allowed for the escape of gases generated by the ISV melt. Posttest analysis of the ISV blocks showed that many of the beads were easily recovered from the surface and that few or none of the beads were incorporated into the ISV melt. The ability of the ceramic beads to float on the ISV melt surface warrants further work to evaluate their insulative properties and other potential applications.

Positive pressure electrode seals performed successfully during all three powered operational stages. The tested set of electrode seals showed no significant deterioration in performance resulting from temperature cycles and repeated electrode movement through the fabric seal openings. The performance of the electrode seals was measured via the amount of air flow required to maintain the set point seal pressure. If the seal had deteriorated substantially, the required air flow rate would have increased; no such increase was observed during testing. Implementation of the positive pressure seal system on field-scale units is planned to eliminate the potential for escape of untreated gases and particulate around the electrode insertion points into the off-gas containment hood. 


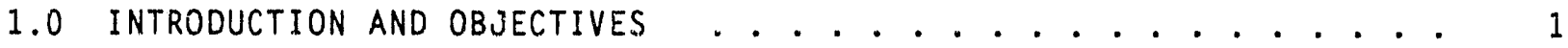

2.0 CONCLUSIONS AND RECOMMENDATIONS . . . . . . . . . . . . . . . . . . 3

3.0 CONCEPTUAL BASES . . . . . . . . . . . . . . . . . . . . . . . 5

3.1 THREE-PHASE, THREE-ELECTRODE POWER SYSTEM . . . . . . . . . 5

3.2 WATER SPRAY SYSTEM . . . . . . . . . . . . . . . . . . . . 7

3.3 LIGHTWEIGHT CERAMIC BEAD LAYER . . . . . . . . . . . . . . . . 10

3.4 POSITIVE PRESSURE ELECTRODE SEALS . . . . . . . . . . . . . 10

4.0 UPGRADED ENGINEERING-SCALE UNIT AND TEST SETUP $\quad$. . . . . . . . . . $\quad . \quad 13$

4.1 POWER SYSTEM . . . . . . . . . . . . . . . . . . . . . 13

4.2 ELECTRODE FEED SYSTEM . . . . . . . . . . . . . . . . 15

4.3 OFF-GAS SYSTEM . . . . . . . . . . . . . . . . . . . . . . 17

4.4 WATER SPRAY SYSTEM . . . . . . . . . . . . . . . . . . . 19

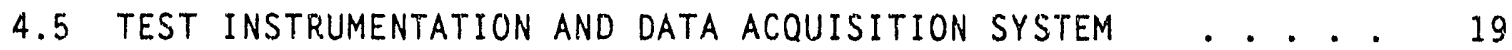

4.6 TEST DESCRIPTION . . . . . . . . . . . . . . . . . . 19

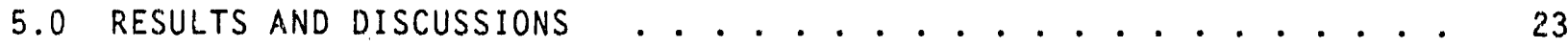

5.1 POWER SYSTEM PERFORMANCE . . . . . . . . . . . . . . . . . 23

$5 . ?$ WATER SPRAY SYSTEM PERFORMANCE . . . . . . . . . . . . . . . . 27

5.3 INSULATIVE CERAMIC BEAO LAYER PERFORMANCE . . . . . . . . . . . 31

5.4 POSITIVE PRESSURE ELECTRODE SEAL PERFORMANCE . . . . . . . . 33

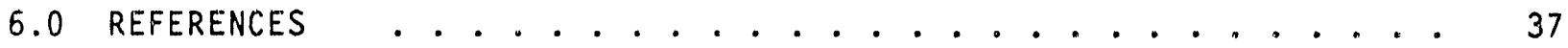

APPENDIX A . . . . . . . . . . . . . . . . . . . . . . 41 


\section{EIGURES}

3.1 Scott Connected Transformer for the Intermediate-Scale ISV Unit . 5

3.2 Temperature and Pressure Profile for 1990 Intermediate-Scale ISV Test at INEL - Test 1 . . . . . . . . . . . . . 7

4.1 Three-Phase Power System for the Engineering-Scale ISV Unit . . . 14

4.2 Schematic of the Engineering-Scale Electrode Feed System . . . . 15

4.3 Schematic of the Positive Pressure Electrode Seal . . . . . . 16

4.4 ISV Engineering-Scale Off-Gas System . . . . . . . . . 18

4.5 Layout for the Engineering-Scale ISV Test Powered Phases . . . . 21

5.1 A-Phase Current and Voltage Profile - Stage 1........ 23

5.2 Total Power Profile - Stage 1 . . . . . . . . . . . 24

5.3 A-Phase Current and Voltage Profile - Stage 2 ........ . 25

5.4 A-Phase Current and Voltage Profile - Stage 3 . . . . . . . . 27

5.5 Total Power profile - Stage 3 . . . . . . . . . . . . 28

5.6 Pressure and Temperature Response for Two 10-s Water Spray System Trials ....................... 29

5.7 Ceramic Bead Configuration Before Start-Up ........... 31

5.8 Early Powered Stage with Molten Soil Showing Through the Beads . 32

5.9 Ceramic Bead Layer Suspended on a Fully Established ISV Melt . . 33

5.10 Surface of ISV Product After Cooldown and Excavation . . . . . . 34

\section{IABLES}

5.1. Positive Pressure Electrode Seal Inlet Air Flow Rates ..... 35

A.1. Numerical Values for Water Spray System Calculations:

Intermediate Scale Off-Gas Hood Conditions and Constants . . . 39 


\subsection{INTRODUCTION AND OBJECIIVES}

In situ vitrification (ISV) is a thermal process that converts contaminated soil into a highly leach-resistant material resembling natural obsidian. The ISV process was developed by the Pacific Northwest Laboratory (PNL)(a) for the U.S. Department of Energy (DOE) to treat soils contaminated with transuranics. Since 1980. ISV has grown from a concept to an innovative technology through bench-, engineering-, intermediate-, and full-scale tests. Efforts by PNL have developed ISV into a technology considered available for limited deployment to remediate contaminated soil. The technology has been transferred to a licensee for commercial application.

A development effort for buried waste applications was initiated in 1988 between PNL and EG\&G Idaho, but further development of ISV for buried waste is currently on hold pending resolution of issues associated with contaminated soil applications. Therefore. PNL applied research and development efforts have been redirected toward completing the ISV technology transfer for contaminated soil applications at DOE sites.

Research conducted between 1988 and 1990 culminated in two intermediatescale ISV field tests performed at Idaho National Engineering Laboratory (INEL) in 1990. The tests were performed to assess the general suitability of the process to remediate waste structures representative of buried waste found at INEL (Callow et a 1. 1991). The tests involved nonhazardous and nonradioactive materials and were designed to provide essential information about the field performance of the ISV process as applied under conditions involving sig. nificant combustible and metal wastes.

Test results indicated the ISV process is feasible for application to buried waste; however, a series of pressure and temperature spikes occurred within the off-gas hood as buried, sealed containers were encountered or influenced by the melt. Such pressure and temperature spikes potentially allow untreated off gases to enter the environment by temporarily pressurizing the off-gas hood to a pressure above that of the ambient environment. These occurrences are called transient events. Research must be conducted to gain an understanding of the mechanisms that lead to transient events. This work must

(a) Pacific Northwest Laboratory is operated by Battelle Memorial Institute for the U.S. Department of Energy under Contract DE-ACO6-76RLO 1830. 
first be conducted at the engineering scale, and based on those results, modifications can be developed to mitigate the effects of tramsient events at the intermediate and full scales. To begin the basic research at the engineering scale, PNL's engineering-scale ISV unit was itself modified to allow for extensive instrumentation and to improve operator safety during test performance.

In September 1591. PNL conducted an operational acceptance test (OAT) of the modified engineering-scale unit. The OAT provided an opportunity to conduct proof-of-principle testing of new concepts for ISV technology. This additional testing was permitted since it was determined that testing of these new concepts would have no impact on the OAT objective. The four main objectives for the proof-of-principle portion of the engineering-scale test were to:

1. evaluate the use of a three-phase, three-electrode configuration. The ISV power system used during the past decade is based on a Scott connected transformer that converts three-phase power into four-phase power for use with a square array of four electrodes. Direct use of threephase power via a three-electrode configuration will increase compatibility with utilities and ininimize unwanted harmonics created by phase conversion.

2. demonstrate the ability of a water spray system to remove energy from the off-gas containment hood plenum, resulting in a decrease in temperature and pressure. PNL is pursuing this technology as a way to suppress the effects of transient events.

3. evaluate the ability of lightweight ceramic beads to float on top of an ISV melt. If the beads remain suspended on the ISV melt. further testing is warranted to evaluate the beads, and similar material, fur use as a floating layer capable of surviving an entire ISV test. Potential applications include insulation. prevention of cold cap rise, assistance in melt subsidence, and reduction in electrode oxidation.

4. evaluate the performance of positive pressure electrode seals. The insertion point for the electrodes through the off-gas containment hood is a potential escape route for gases during a positive pressure event. positive pressure electrode seals would eliminate this risk.

In discussing the proof-of-principle portion of the engineering-scale test, this report presents conclusions from this work and also describes the conceptual bases of the tested concepts, the engineering-scale test equipment and setup. and test results. 


\subsection{CONCLUSIONS AND RECOMMENDATIONS}

The four new concepts were successfully tested during the September 1991 OAT. Analysis of test data and observations provided the following conclusions :

- The three-phase, three-electrode power supply system successfully initiated and sustained the ISV process, producing a $830 \mathrm{~kg}$ block and consuming $810 \mathrm{kWh}$ of energy. This successful test shows that the three-phase, three-electrode power supply system is a viable alternative to the scott connected transformer.

- The water spray system designed to reduce the effects of pressure and temperature transients in the off-gas containment hood successfully reduced pressure and temperatures in the off-gas hood during multiple trials. This system has great potential to perform this task at the field scale and warrants further evaluation.

The lightweight ceramic beads used to insulate the melt are able to survive the ISV process and remain floating on the melt surface. These abilities of the lightweight beads are the basis for proposed ISV applications using the beads. Future work is recommended to further investigate use of the beads for the ISV technology for such applications as promoting melt subsidence, insulating the melt surface, and reducing electrode oxidation.

- The positive pressure electrode seals, placed at the electrode insertion points into the off-gas containment hood, maintained their seal pressure with minimal air inlet flow. Pressure within the seal is the key to preventing the release of untreated material to the environment through the seal itself. Implementation of the positive pressure electrode seals in the field will eliminate the potential release of untreated gas and particulate from the electrode penetration points on the hood. 


\subsection{CONCEPTUAL BASES}

The following subsections describe the conceptual bases of each of the four new concepts that were evaluated during the engineering-scale test.

\subsection{IHREE-PHASE. THREE-ELECTRODE POWER SYSTEM}

The ISV technology currently uses a power system consisting of two quadrature phases (Scott connection) to energize a square array of four electrodes. The square array was designed to create cube shaped melts for remediation of linear trenches or rectangular landfills. Experience with this power system at the bench, engineering, intermediate, and full scales, however, has demonstrated that the resulting melt is ultimately a truncated teardrop shape and not the desired cube shape. Consequently, the compatibility of the ISV power supply with three-phase electrical utilities is being pursued and a three-phase, three-electrode system is under development. In addition to compatibility with utilities, such a power system is believed to have better control characteristics than the presently used system.

Difficulties controlling and operating the four-phase Scott connected transformer, to which power is supplied by a three-phase utility, arise from the resonant character of the scott connected transformation. Figure 3.1

Silicon Control Rectifiers

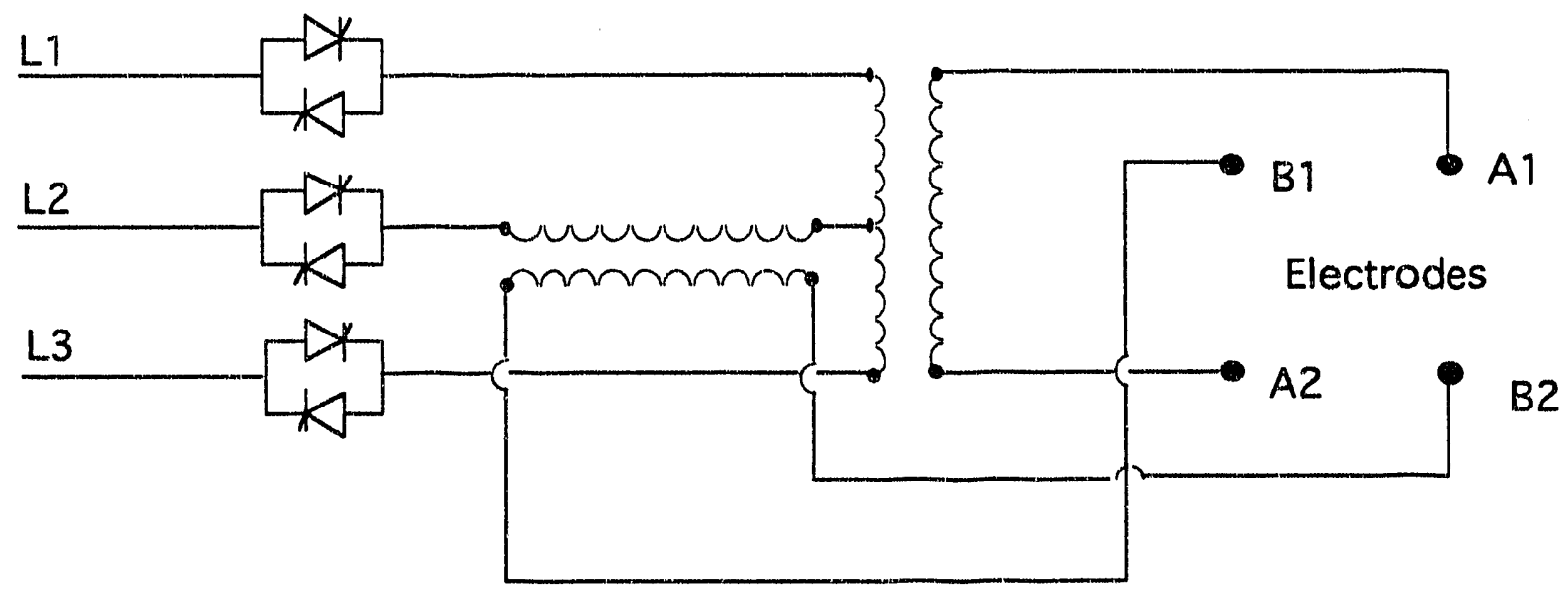

FIGURE 3.1. Scott Connected Transformer for the Intermediate-Scale ISV Unit 
illustrates the Scott connected transformer for the intermediate-scale ISV unit. The scott connected transformer converts a three-phase (four wire) system to a four-phase (five wire) system; the omission of the neutral conductors yields the usual three-phase to four-phase configuration. To accomplish this, the tapped winding must resonate between its halves and operate one winding at a leading power factor of $30^{\circ}$ and the other winding at a lagging power factor of $30^{\circ} .(a)$

These balanced phase shifts require that the electrical utility supply three voltages of equal magnitude, separated by phase angles of $120^{\circ}$. The two secondary windings yield quadrature voltages which. when ungrounded, provide the four-phase voltages that are of equal magnitude separated by $90^{\circ}$ only if the secondary loads are equal and of unity power factor (these loads are often not equal for ISV applications, which are often performed on heterogeneous sites). This unique balance of currents and voitages is valid for one frequency. When harmonics are generated by saturable reactors or by semiconductor devices to control load voltages and currents within the Scott connected transformer. this unique balance is disrupted.

The preceding discussion of the infrastructure of the scott connected power supply illustrates the difficulties experienced in control and operation of the ISV process. To avoid such difficulties, efforts were initiated to identify an alternative power supply system for the ISV technology. Since multiples of three phases are compatible with utilities worldwide, the use of saturable reactors and/or semi-conductors in these three-or six-phase transformation systems permits avoidance of the operating difficulties encountered with the Scott connected system.

Although power transformation systems based on multiples of three do not share the adverse behavior characteristics of the Scott connected system. the generation of harmonics from nonlinear active controls is still a concern. The use of nonlinear saturable reactors and semi-conductors for active control can cause difficulty for utilities when load currents are excessive. This utility limitation restricts the use of these harmonic generating control devices in units subject to a large demand. However, this limitation is a function of the capacity of the supplying utility generator. Control units

(a) Detailed descriptions of the scott connected transformer may be found in Westinghouse Electric Corporation (1950). Liwchitz-Garik and Whipple (1961). Massachusetts Institute of technology (1950), and Elgard (1982). 
with a lesser power rating may allow the use of these halmonic generating control systems because the utilities are insensitive to or can toierate. small differences.

\subsection{WATER SPRAY SYSTEM}

Intermediate-scaie ficld tests on simulated buried waste conducted at INEL in 1990 demonstrated the feastbility of using ISV for buried waste applications (Callow et al. 1991). However, the 1990 tests also demonstrated that the procassing of buried waste (specifically sealed containers) is more dynamic than for contaminated soil applications. Figure 3.2 illustrates the temperature and pressure proftle for Test 1 of the 1990 intermedtate-scale field tests performed at INEL. The time period in which the temperature and pressure spikes occurred correspond to the period of tithe in which the simulated buried waste was processed. It is believed that the reiease of gases

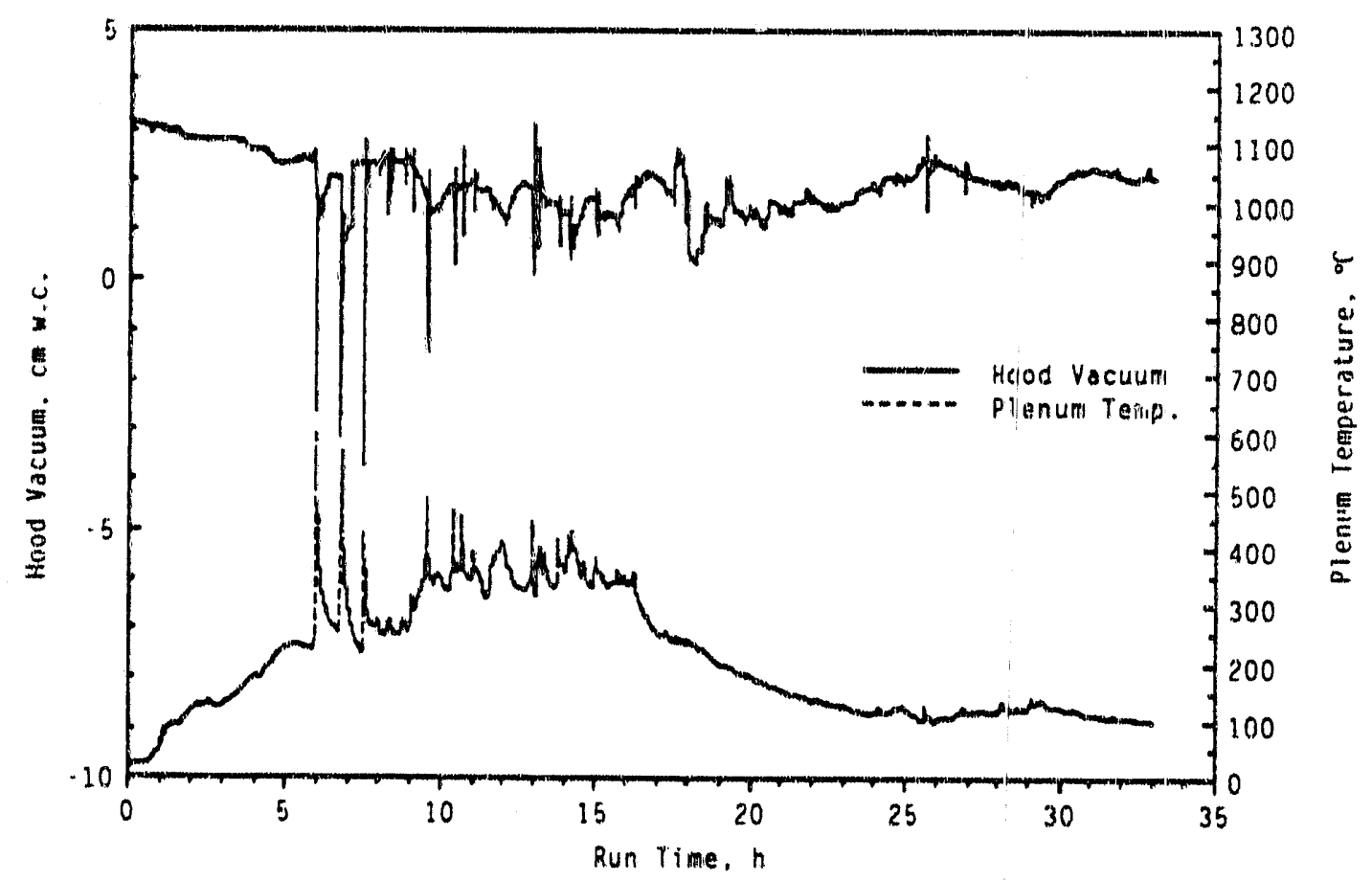

ElGURE 32. Temperature and Pressure Profile for 1990 Intermediate-Scale ISV Test at INEL. Test 1. Adapted from Call ciw et al. 1991. 
from sealed containers into the hood was che underlyiilg cause for the transient events observed during the 1990 test.

Based on the research conducted by PNL and INEL, the mechanisms by which the off-gas hood may becoine positively pressurized can be organized into three general areas:

1. net energy increase of gases in the hood. Which may be caused by:

- addition of hot gases from the ISV melt.

- combustion of pyrolysis gases in the hood

- increased radiant and convective heating of gases in the hood due to changes at the melt surface

2. net increase in number of moles of gases in the hood

3. net increase in both energy and number of moles of gases.

The off-gas hood is much like a gas-filled tank. At steady-state, with equivalent inlet and outlet streams, the tank will remain at a constant pressure. However, the tank or hood pressure will increase when either the material flow into the tank increases or the temperature of the gases within the tank increase. or if both material flow and temperature incrase. In the case of the ISV off-gas hood, as with the gas-filled tank, the increase in pressure is proportional to the magnitude, but more importantly to the rate, at which energy and/or material is added to tine off-gas hood.

PNL is pursuing concepts for engineered systems designed to mitigate transient events in the off-gas hood that are the result of net energy and/or material increases within the off-gas hood. One such system that shows great promise is a water spray system. Calculations indicate that a water spray system can be designed to remove energy from the gases in the off-gas hood by evaporative cooling, thus mitigating the pressure increases associated with transient gas releases from the ISV melt.

The premise for the water spray concept is based on the ideal gas law in which pressure is proportional to temperature for given volume and number of moles. During a transient pressure event (caused by energy and/or material addition to the off-gas hood), water is sprayed into the off-gas hood to remove energy from the gases in the hood. Energy transferred from gases within the hood is used to vaporize the added water. This energy transfer 
leads to an overall temperature decrease in the hood plenum. As a result of this temperature decrease. the pressure within the off-gas hood also decreases. (a)

Water was selected for the gas quenching stream due to its high heat of vaporization, the main driving mechanism for the removal of energy from gases in the off-gas hood. Liquid nitrogen and carbon dioxide were also evaluated but were determined to be less efficient because it would require almost nine times as many moles of nitrogen and six times as many moles of carbon dioxide to remove the same a ount of energy that one mole of water could absorb. This difference is mainly due to the higher heat of vapcrization for water $(40.58 \mathrm{~kJ} / \mathrm{mole}$ ) relative to that for nitrogen and carbon dioxide, $5.43 \mathrm{~kJ} / \mathrm{mole}$ and $8.37 \mathrm{~kJ} / \mathrm{mole}$, respectively. Also, water at $20^{\circ} \mathrm{C}$ is much easier to handle than either liquid nitrogen or solid carbon dioxide (solid carbon dioxide sublimes at $-78^{\circ} \mathrm{C}$ ).

The water spray system tested during the engineering-scale operational acceptance test was based on calculations performed to estimate whether the use of a water spray in the off-gas hood could effectively cool the off gases and subsequently increase the hood vacuum in the event of a pressurization. Numerical expressions were developed based on the kinetic theory of gases to estimate the effectiveness of a water spray suppression system assuming that a sudden release of high energy gases (e.g.. $1200^{\circ} \mathrm{C}$ water vapor) from the region being vitrified causes the observed hood pressurizations. The calculations were based on instantaneous energy balances (i.e.. inlet and outlet flow rates were ignored). Calculations based on heat capacity data were used to check those based on kinetic energy.

An evaluation of the water spray system was performed for $12 \mathrm{gmol}$ of steam $\left(1200^{\circ} \mathrm{C}\right)$ entering the off-gas hood from the surface $0^{\circ}$ the ISV melt (Appendix A). This evaluation shows that 13.9 gmol of added water could counter the effects from a 12 gmol release of steam from the ISV melt (temperature lowered to $549.1 \mathrm{~K}$ from $597 \mathrm{~K}$ and pressure lowered from $106.98 \mathrm{kPa}$ to $100.68 \mathrm{kPa})$. The basis for the success of the water spray system is the ability of the added water to remove energy from the gases in the hood through the vaporization of the added water. However, the calculations are based on steady-state energy balances and neglect unsteady-state conditions in the offgas hood during a transient event. Further work is needed to evaluate the

(a) The water spray concept has also been utilized in the nuclear industry for accelerated pressure reduction (Leardini and Cadeddu 1961). 
application of a water spray system and include determination of optimal droplet size, determination of the energy transfer rate, and a fundamental understanding of the mechanisms which lead to transient events (i.e. pressure and/or temperature spikes) in the off-gas hood.

\subsection{LIGHTHEIGHT CERAMIC BEAD LAYEB}

After a starter path has been laid between the electrodes to initiate the ISV process, a layer of insulative material is typically placed over the zone to be vitrified. The purpose of this insulative layer is to prevent heat loss during start-up. thereby permitting a greater portion of the heat produced in the starter path to be directed into the suil to effect vitrification. After the soil becomes molten. the purpose of the insulative layer is to reduce heat loss, which eliminates cold cap rise and enhances melt subsidence (Buelt et al. 1987). The reduced heat loss in turn leads to improved melt propagation and a more efficient use of power supplied to the ISV melt. Currently. ISV melts are insulated by a blanket of Kaowoolo, which is made of refractory ceramic fibers. Kaowool performs adequately during heating of the starter path but does not survive once the melt is well established (i.e.. it is incorporated into the melt. leaving the melt surface exposed).

Lightweight ceramic beads are being evaluated to replace kaowool as a means of insulating the melt surface throughout an entire ISV test. In addition to reducing heat loss through the melt surface, the layer of beads would reduce a rising cold cap, assist in melt subsidence, and potentially reduce electrode oxidation. The principle is simple: at the beginning of the test. a layer of ceramic beads is placed over the site in a manner similar to Kaowool. As the soil becomes molten, the ceramic beads should continue to insulate the ISV melt since it is predicted that they will float on the melt surface. A key assumption is that the beads will continue to float on the ISV melt surface during processing (e.g.. the beads will not be incorporated into the melt via convective currents nor dissolve into the molten soil). When this assimption is validated, further testing to determine the applicability of the bead layer will be performed.

\subsection{POSIIIYE PRESSURE ELECTRODE SEALS}

During normal operation of the ISV system, the off-gas containment hood is maintained at a negative pressure relative to the ambient surroundings. 
This pressure difference is the driving force for gas flow into the off-gas containment hood (e.g.. through the combustion air inlet line and through paths around the electrode insertion points). However, during pressurization of the off-gas containment hood, the preferential gas flow is out of the hood because the pressure within the hood is greater than the ambient surroundings. The combustion air inlet line has a high-efficiency particulate air (HEPA) filter in a by-pass line that prevents the release of contaminated particulate, but there is no such safety feature around the electrode insertion points. The positive pressure electrode seals were developed to prevent gas escape through these openings.

The principle of the positive pressure electrode seals is to maintain a pressure gradient at the seals so that gas flow is always into the off-gas containment hood. Air is forced into a seal chamber placed at the electrode penetration point. The flow into this seal chamber is controlled so that the seal chamber remains at a set point pressure (e.g.. $20 \mathrm{kPag})$. During normal operation. small amounts of air pass through the seal chamber into the off-gas containment hood, as well as to the ambient atmosphere. While allowing air to pass through, the seal chamber is maintained at a pressure of $20 \mathrm{kPag}$. During a positive pressure event. the seals prevent gases from escaping since the pressure in the seal chamber remains greater than the pressure inside the hood, thereby maintaining the preferential gas flow into the hood.

Proof-of-principle testing is required to determine 1 ) the effects of temperature on the electrode seals, 2) the flow rate required to maintain a positive seal pressure, and 3 ) the effect on the seals of electrodes moving through the seals. Items 1 and 3 are important to assess the potential rate of seal degradation temperature and physical wear. Item 2 is important to assess the ability of the system to be adapted to field-scale units. 


\subsection{UPGRADED ENGINEERING-SCALE UNIT AND TEST SETUP}

Previously, the engineering-scale system was designed to test ISV for soil applications. However, the focus of engineering-scale testing has been expanded to include applications for buried waste, underground tanks, and other energetic waste forms. Because transient pressure and temperature events are more likely to occur during applications to buried waste (sealed containers) and underground tanks, the engineering-scale system was upgraded to enable research to be conducted in a safe manner. The upgrades to the ISV engineering-scale system include:

- large diameter $(1.83 \mathrm{~m})$ steel-flanged container and quick release lid system

- positive pressure electrode seals

- separate overflow volume (extension of melt plenum space, which remains unaffected by the radiant thermal effects of the melt and serves as an expansion volume for dynamic pressure events)

- continuous measurement of the inlet combustion air and outlet off-gas flow by electronic data acquisition system (DAS)

- continuous measurement of the plenum space pressure by electronic DAS

- flexibility for testing various electrical configurations

- ability to test prototype off-gas treatment system components.

In addition to providing a safe operating system for the study of dynamic events, the upgrades have resulted in an easier and more efficient test setup. The following subsections describe the engineering-scale unit equipment and setup for the new ISV concepts evaluated in this report.

\subsection{POWER SYSTEM}

For this test, a three-phase, $480 \vee A C$ system supplied power to three 5-cm diameter. solid graphite electrodes that were spaced $52.8-\mathrm{cm}$ apart in an equilateral triangle. The three-phase system consists of a $90 \mathrm{~A}$ disconnect and a $75 \mathrm{kVA} 480 / 208 \mathrm{~V}$ delta/wye transformer with a variac on each phase to control power output. The three-phase power system is shown in Figure 4.1. A provision was made to attain higher voltage for start-up by simply bypassing the transformer and supplying the 480 VAC from the disconnect directly to the variacs and on to the electrodes (see Section 5.1 for a discussion of the requirements for additional voltage). This provision created an electrical 


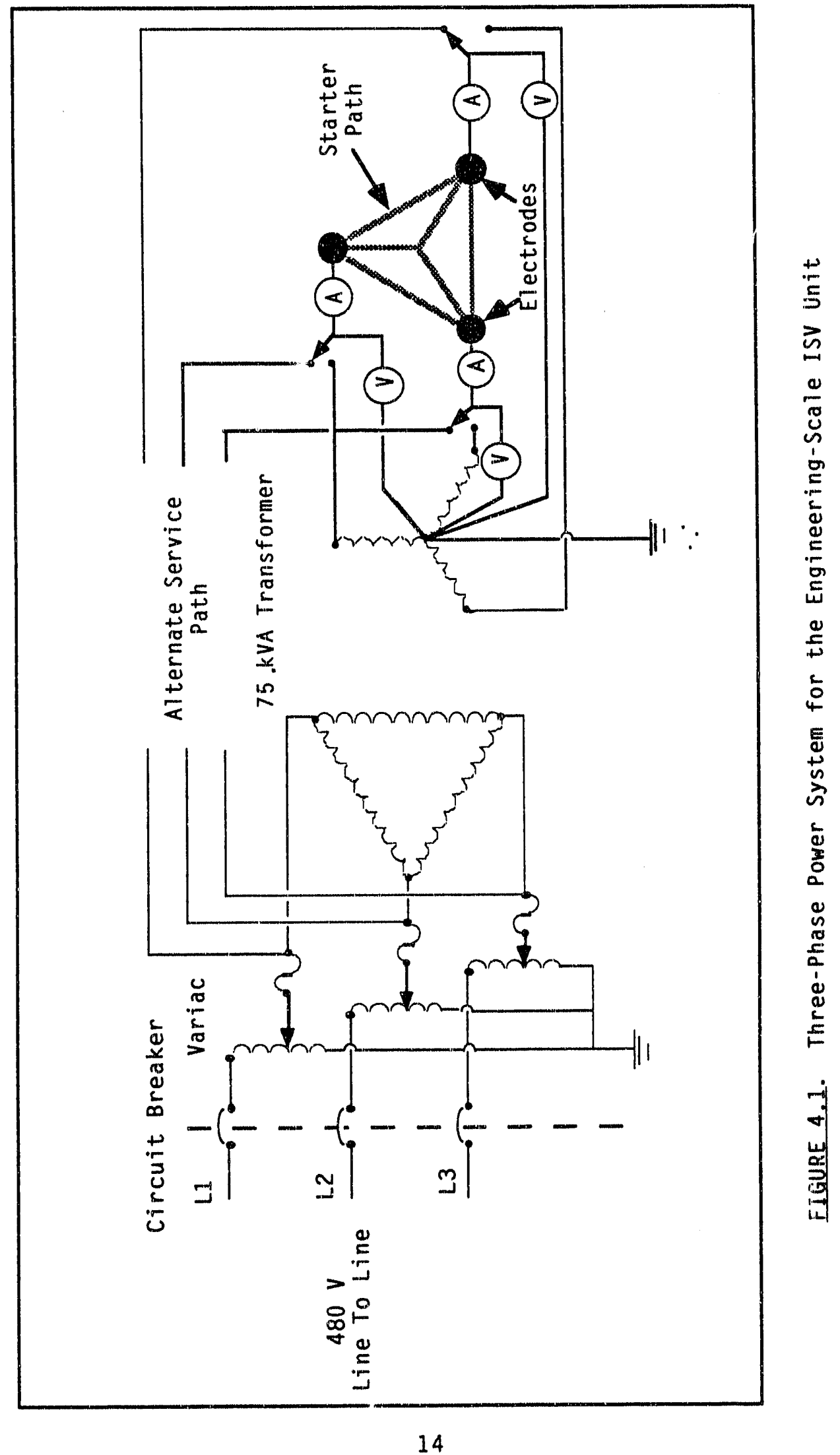


potential of 277 VAC with a 90 A limit as opposed to 207 VAC and a 200 A limit through the transformer windings. Voltage was measured with digital multimeters. which also measured the potential between ach phase and the neutral leg. Current measurements were taken on the conductor leading to each electrode.

\subsection{ELECTRODE FEED SYSTEM}

Figure 4.2 illustrates the electrode feed system. The electrode feed system provides a means of controlling the vertical position of the electrodes in the ISV melt. The feed system consists of a pair of electrical contactors, a gripper that holds the electrode and is capable of travelling vertically. and a pneumatic drive and control system used to actuate and move the gripper. Under typical conditions, the electrodes are gravity fed into the soil (grippers not actuated), and they follow the progressing melt front downward. If conditions in the melt change (e.g., electrodes establish contact with the molten metal pool at the melt bottom, causing a direct short), the electrodes can be gripped and retracted out of the shorting condition without process

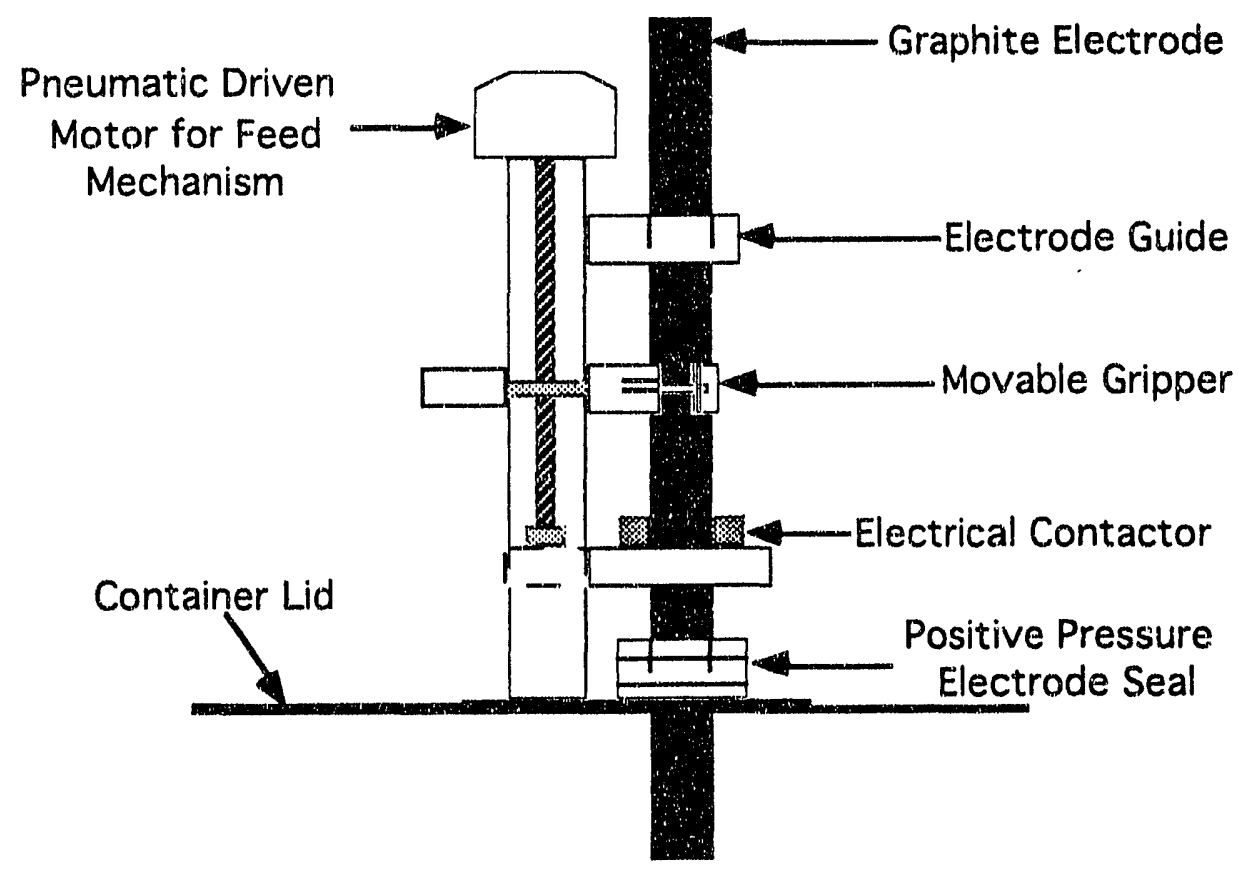

EIGURE 4.2. Schematic of the Engineering-Scale Electrode Feed System 
delays or lost time. The electrode feed system is also a useful tool for electrode recovery in the event of breakage.

The electrode feed systein comprises three assemblies (the number dependent on the number of electrodes used) mounted atop the lid of the engineeringscale test unit. Each assembly is fitted with a positive pressure seal at the point where each electrode penetraies the hood. Figure 4.3 illustrates the components of the positive pressure seal. Each seal is pressurized to $20 \mathrm{kPag}$ to eliminate the escape of off gases from the engineering-scale container. The seal is constructed of six layers of silicon-coated. high-temperature fabric sandwiched between layers of rigid nonconductive plates. The diameter of the opening in the fabric is smaller than the diameter of the electrode. thus creating a seal. Compressed air is forced between the inner layers of fabric to pressurize the chamber volume and provide an impermeable zone due to the pressure differential between the container and the seal. The seal pressure is coordinated with the filtered pressure relief valve for the process container. The relief valve is

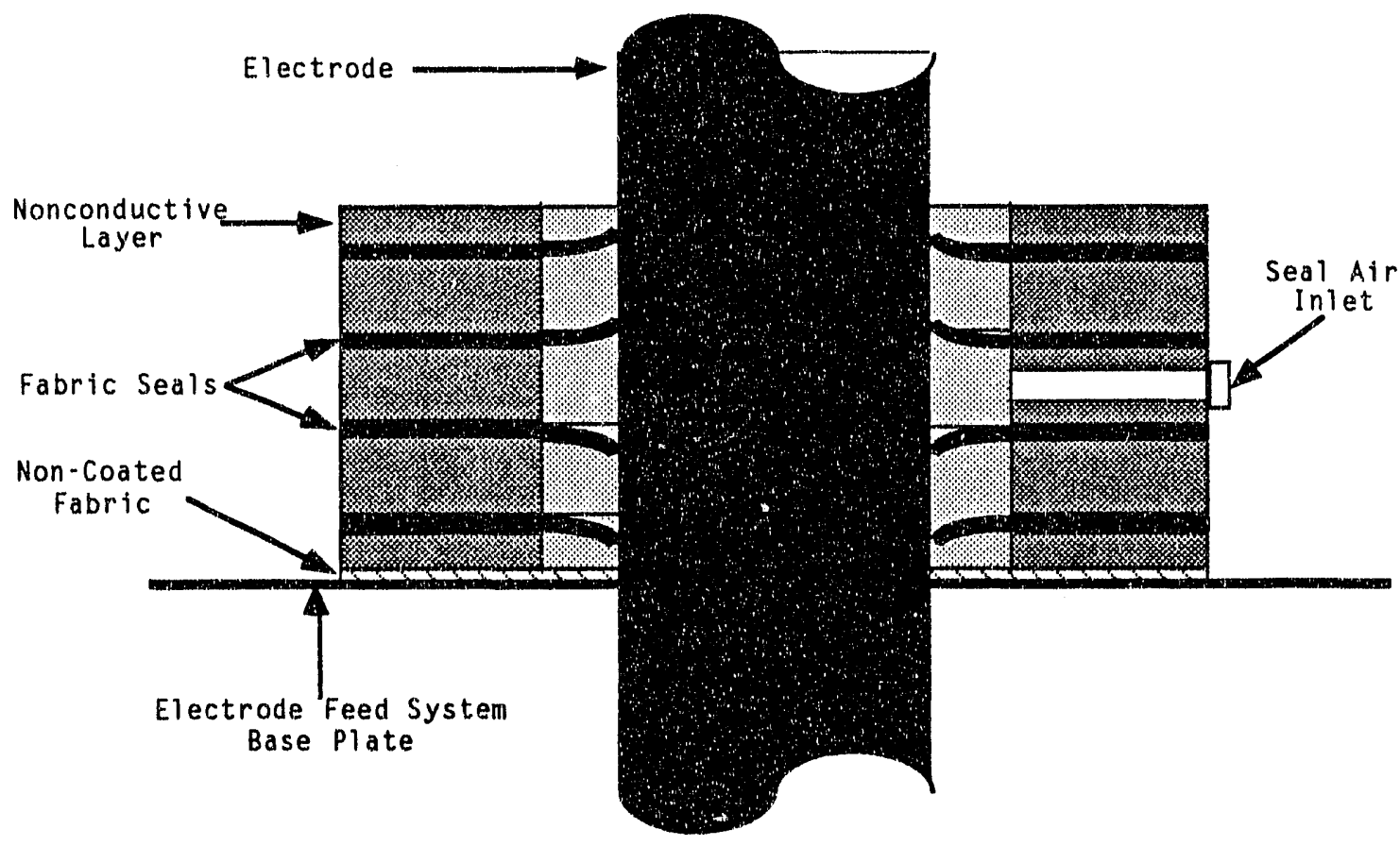

EIGURE 4.3. Schematic of the Positive Pressure Electrode Seal 
actuated at a lower pressure than that maintained in the seal chamber to direct all excess gas volume through the relief valve. The silicon-coated fabric is protected from glass splatter by a layer of uncoated hightemperature fabric at the interface of the seal with the inside of the container.

For this test, the electrodes were gravity fed into the melt with periodic actuation of the feed system gripper to drive the electrodes to the bottom of the melt. The weight alone of the enginersing-scale electrodes proved insufficient to overcome the friction created by the passing of the electrodes through the seal fabric. The weight of both intermediate- and fullscale electrodes will be more than adequate to permit gravity feeding through the electrode seals.

\subsection{DFF-GAS SYSTEM}

The off-gas system for the engineering-scale ISV unit consists of both the containment and the treatment systems (Figure 4.4). The off-gas system is composed of a 1.83-m-diameter by $2.44-m-t a l 1$ stainless steel container with a frustum shaped lid, gas expansion volume, condenser, knockout pot, gas heater. HEPA filter, and control valve. Inlet air is provided through a $5-\mathrm{cm} 1$ ine located directly opposite the off-gas outlet. Flow rate can be controlied at either the combustion air inlet line or at the outlet line, or a combination of both simultaneously. The off-gas outlet flow is generated by the vacuum/blower system housed in the 324 Building.

The off-gas system is designed to withstand pressure up to $41.4 \mathrm{kPag}$. Administrative controls for the system are set at $13.8 \mathrm{kPag}$. A pressure relief valve set at $13.8 \mathrm{kPag}$ gives the system an acceptable safety margin and decreases the possibility of system component failure due to pressurization above design limits. This pressure relief valve is connected by a line to a HEPA filter. which prevents the escape of contaminated particulate from the engineering-scale unit.

The engineering-scale unit was designed to include two steel expansion tanks that serve to buffer transient events in the off-gas container. The expansion tanks are connected to the engineering-scale container by an $20.3-\mathrm{cm}$ line. The tanks have a combined total volume of $1.334 \mathrm{~m}^{3}$, which is in addition to the $2.31 \mathrm{~m}^{3}$ of plenum space already provided in the off-gas container. In principle, the expansion volume provided by the tanks is simply 


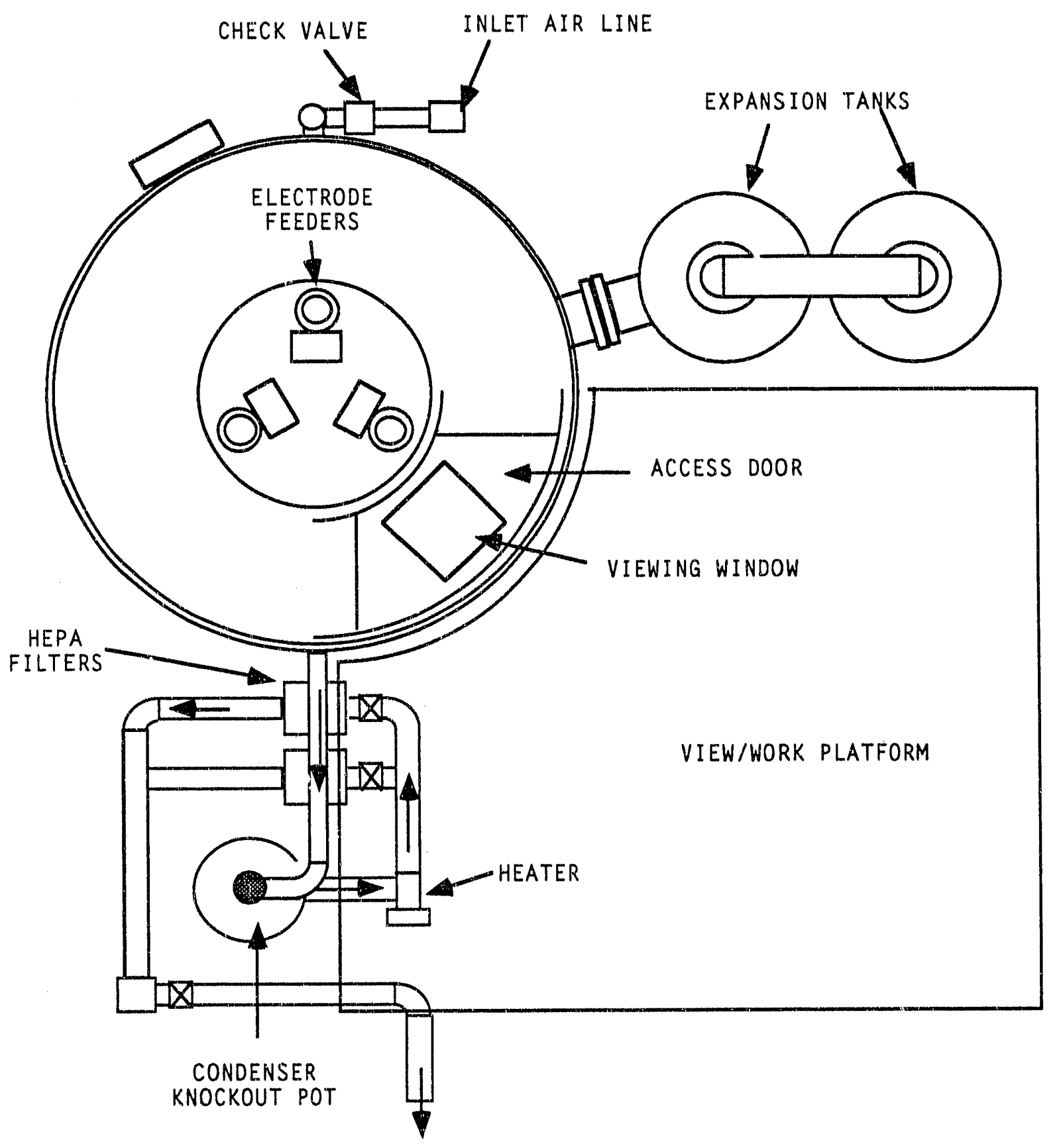

TO BUILDING VACUUM SUPPLY

EIGURE 4.4. ISV Engineering-Scale Off-Gas System 
an extension of the plenum space in the off-gas container. thereby increasing the volume available for the expansion of gases due to thermal exposure. The expansion tanks can be separated from the off-gas container through the use of a blind flange so that transient events may be studied with and without the additional expansion volume.

\subsection{WATER SPRAY SYSTEM}

The water spray system consists of a single spray nozzle located at the center of the engineering-scale lid. The nozzle is designed to deliver a $30^{\circ}$ conical spray pattern at a flow rate of $2.23 \mathrm{~L} / \mathrm{h}$ for a $668.8 \mathrm{kPa}$ water supply. For this test, the operation of the spray nozzle was actuated with a manual valve. Water was filtered before being allowed to enter the spray nozzle. Implementation of the water spray system into a field-scale ISV processing unit will involve coupling the control operations of the water spray system to instrumentation monitoring conditions within the off-gas hood. The number of spray nozzles needed and the required water droplet size will be determined based on plausible transient event scenarios.

\subsection{IEST INSTRUMENTATION AND DAIA ACQUISITION SYSTEM}

Two DASs were used to collect data generated during the engineeringscale operational acceptance test. The power data was collected on an IBM PC (one sample per second). Instrumentation for the power system was connected as noted in subsection 4.1. Soil thermocouple measurements were recorded both on a strip chart recorder and the primary DAS, which consists of a Macintosh II $c x$ computer. Labview data acquisition software, and a two-wire transmitter for each thermocouple to provide linearization and isolation. Pressure measurements were taken with variable reluctance differential pressure (vrdp) transducers, which output information directly to the primary DAS. The inlet and outlet flows were measured using averaging Pitot tubes coupled with a vrdp. also output directly to the primary DAS. The frequency of data sampling was adjusted as needed during various portions of the test.

\subsection{IEST DESCRIPIION}

Figure 4.5 illustrates the setup and instrumentation for the OAT. Nonhazardous, nonradioactive Hanford soil was used for each of the powered phases. A $2.5-\mathrm{cm}$-thick layer of shredded paper was added at the $20.3-\mathrm{cm}$ soil 
level for stages 1 and 2 , and $1 \mathrm{~kg}$ of an oil/soil mixture was added at the $20.3-\mathrm{cm}$ soil level for stage 3 . The purpose of these layers was to provide a combustion source to raise the pleinum temperature above $150^{\circ} \mathrm{C}$. The high plenum temperature was necessary to challenge the operating system and adequately test the energy removal by the water spray system. Type $K$ thermocouples were placed vertically along the soil centerline every $15.2 \mathrm{~cm}$ and inserted to a depth of $121.6 \mathrm{~cm}$. Also, three type $K$ thermocouples were $p l a c e d$ iaterally at the $91.4-\mathrm{cm}$ depth at distances $30.5 \mathrm{~cm}, 45.7 \mathrm{~cm}$, and $61 \mathrm{~cm}$ from the centerline. The thermocouples were used to track the progressing ISV melt front.

The starter path illustrated in Figure 4.5. which consists of a mixture of $65 \%$ graphite and $35 \%$ glass frit by volume, was placed between the electrodes in strips that were $2.5-\mathrm{cm}$ wide by $2.5 \mathrm{~cm}$ deep. A $1.25-\mathrm{cm}$ wide by $2.5-\mathrm{cm}$ deep layer of pure graphite was placed around the electrodes at the interface to the starter path to increase electrical conductivity between the electrodes and the starter path. For a smooth and balanced start-up. the starter path was placed in both a delta and wye pattern (see Figure 4.1 for illustration). The delta/wye starter path is comparable to the " $X$ " and square pattern used in the four electrode configuration with the scott connected transformer. A $2.5-\mathrm{cm}$ layer of soil was placed over the starter path to reduce the entrainment of particulate in the off-gas created during the consumption of the star er path. Within the area between the electrodes. a $3-$ to $6-\mathrm{cm}$ layer of lightweight ceramic beads was placed over the $2.5-\mathrm{cm}$ soil 1 ayer. The beads are approximately $3.2 \mathrm{~mm}$ in diameter and composed primarily of alumina.

The three powered operational stages were conducted between September 3 and September 12, 1991: stage 1, September 3; stage 2. September 5 and 6: and stage 3. September 11 and 12 . Originally, only two stages were planned, but. as will be discussed in subsection 5.1, voltage limitations at the beginning of stage 1 prematurely ended the stage. Stage 2 was used to familiarize operators with the operation of a three-phase, three-electrode system. Stage 3 built upon the experiences gained in stage 2 and was continued until a melt. depth of $107 \mathrm{~cm}$ was reached.

At various times during stages 2 and 3 , the water spray system was activated, and the effects on the off-gas hood conditions were recorded on the primary DAS. The purpose of these water spray trials was to confirm that the addition of water to the hood would cool the plenum space. thereby increasing 


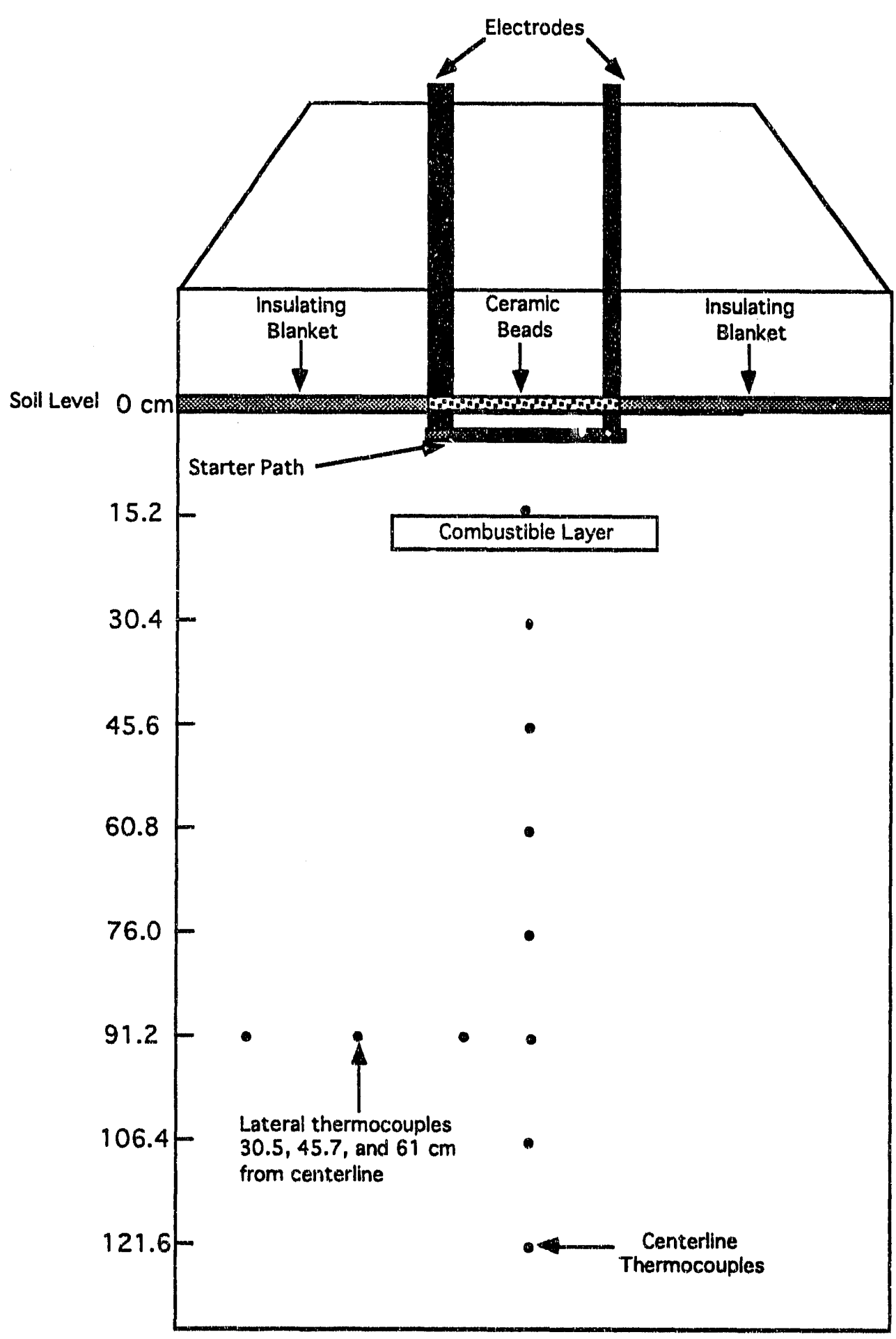

EIGURE 4.5. Layout for the Engineering-Scale ISV Test Powered Phases. Figure not drawn to scale. 
the vacuum in the hood. Simulated transient events were not performed during the three stages (details about the results of the water spray system tests are given in subsection 5.3 ).

For all three powered stages, a lightweight ceramic bead layer was used as an insulative blanket over the area to be vitrified. Observations during the test and during excavation of the ISV block indicate that the beads both survived the meit and floated intact on the surface (specifics related to the ceramic bead layer are discussed in subsection 5.4). 


\subsection{RESULTS AND DISCUSSIONS}

The following subsections discuss the test results for each of the four new concepts evaluated during the engineering-scale operational acceptance test. Qverall. the proof-of-principle testing of the fol:r new concepts demonstrated that each of the concepts will potentially benefit ISV technology. Test results for some of the concepts raise technical issues: however. it is recommended that these technical issues be addressed in future work to develop these concepts for field-scale evaluations.

\subsection{POWER SYSTEM PEREORMANCE}

Using the three-phase, three-electrode power system, stage 1 was energized from the $120 \mathrm{~V}$ wye-connected winding of the $480 \mathrm{~V}$ delta/wye $75 \mathrm{kVA}$ transformer to provide starting electrode voltages of $120 \mathrm{~V}$ or less. Figure 5.1 illustrates the current and voltage profile during stage 1 for the $A$ phase (each electrode was powered by one electrical phase, denoted A, B, and c).

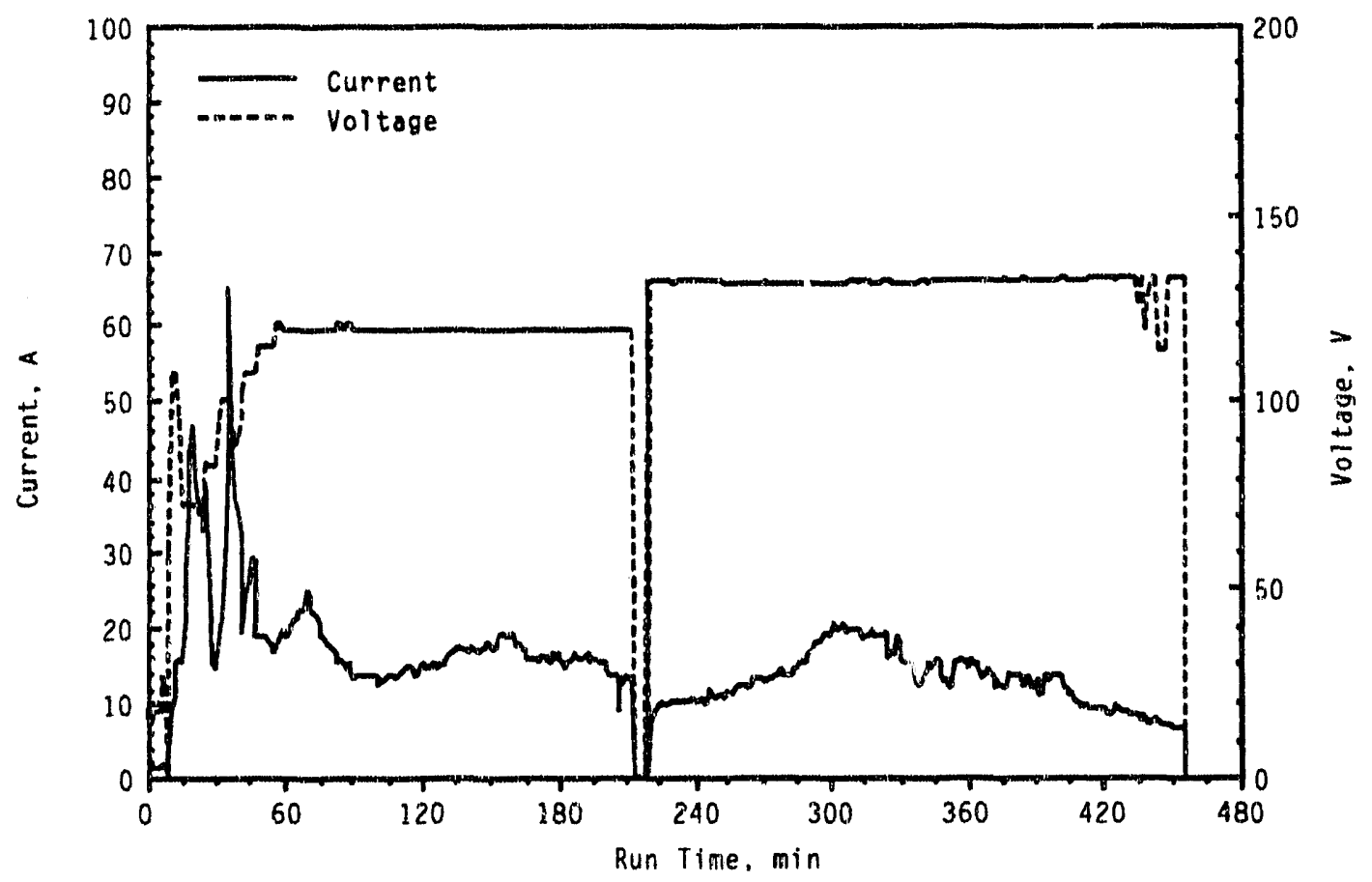

EIGURE 5.1. A-Phase Current and Voltage Profile - Stage 1 
Abrupt changes in voltage and current are evident during the start-up period (the first $60 \mathrm{~min}$ ), reflecting the inexperience using independent phase controllers on a three-phase, three-electrode system.

Also evident in Figure 5.1 is the fact that the power system became voltage limited. This limitation prevented input of adequate power to the newly initiated melt and ultimately resulted in the termination of stage 1. The $120 \mathrm{~V}$ (line-to-neutra1) limit from the transformer was increased to $132 \mathrm{~V}$ after the taps on the $75 \mathrm{kVA}$ transformer were reconfigured ( $\approx 215 \mathrm{~min}$ into the test). Because of economic constraints, the three-phase proof-of-principle testing was conducted with equipment immediately available. Had a three-phase system designed specifically for ISV application been available, voltage or current limitations could have been avoided by using the appropriate voltage taps. As illustrated in Figure 5.2, this higher voltage level of $132 \mathrm{~V}$ was insufficient to substantially increase the power input to the soil.

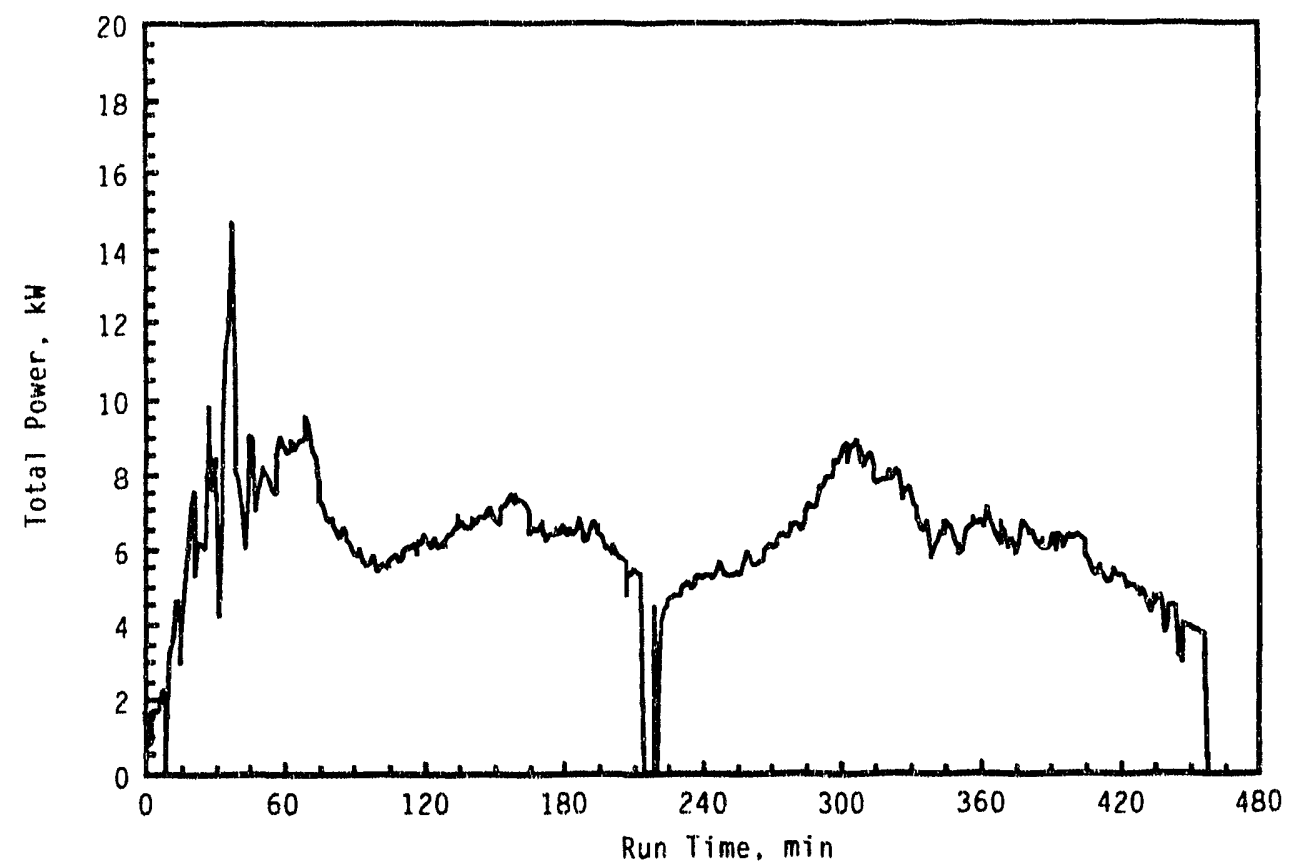

EIGUBE 5.2. Total Power Profile - Stage 1 
After stage 1, it was evident that a higher starting voltage (>132 V) was needed. Consequently, the 75 kVA transformer was switched out of the circuit and a maximum of $480 \mathrm{~V}$ (line-to-line) was applied to the electrodes. yielding a $277 \mathrm{~V}$ line-to-neutral potential on the electrodes. This change allowed successful power operation throughout stage 2 . Figure 5.3 illustrates the stage 2 current and voltage profile for A-phase. The periods of downtime shown in Figure 5.3 (except for downtime $130 \mathrm{~min}$ into the test) were due to difficulties with the electrical contactor for one electrode.

At the 130 -min mark, the fuses for the $C$-phase variac burned out. The cause for the current overload of these fuses was the increase in current flow while the electrodes were manually fed further into the melt. As the electrode surface area contacting the ISV melt increased, so did the amount of current flowing through the melt and the electrodes. The operating procedure for the remainder of stage 2, and for stage 3, was changed so that the variacs were turned down before manual feeding of the electrodes commenced. The blown fuses are another example of the consequences of conducting proof-of-principle testing with existing equipment. The stacked variacs used for power control

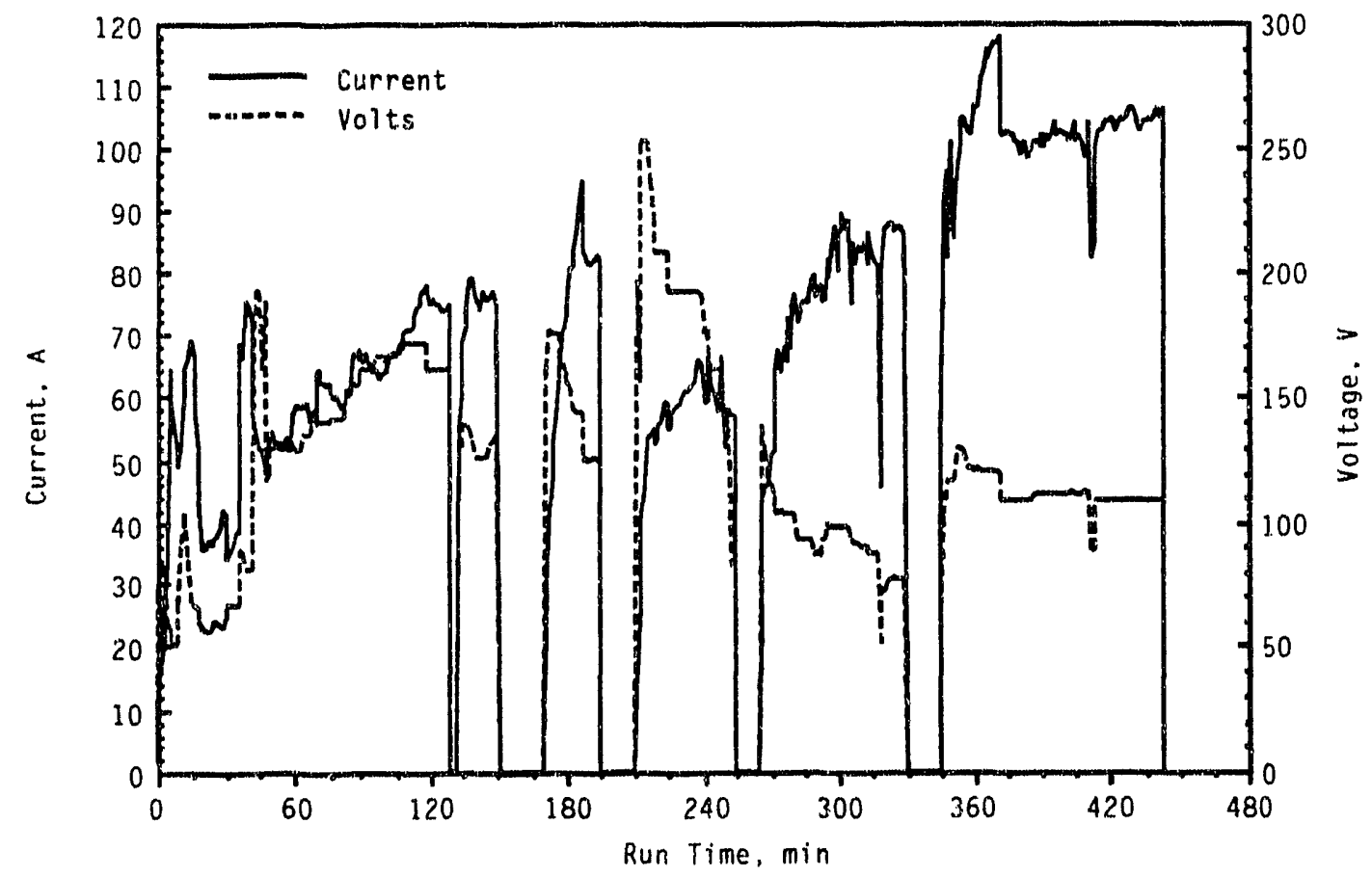

EIGURE 5.3. A-Phase Current and Voltage Profile - Stage 2 
were required to operate at full capacity, though without any overload capacity. Therefore, the performance of the variacs in the OAT is not particularly useful in predicting future performance of three-phase power supply at the field scale.

As melt resistance decreases due to the growth of melt volume, increased electrical current is required to maintain the power level supplied to the melt. The current was enhanced by rerouting power through the $75 \mathrm{kVA}$ transformer. which increased the maximum current flow from $90 \mathrm{~A}$ to $205 \mathrm{~A}$ and lowered the attainable voltage from $277 \mathrm{~V}$ line-to-neutral to $120 \mathrm{~V}$ line-toneutral. However, as shown in Figure 5.3, maximum current demand was below 120 A for a power level of approximately $35 \mathrm{~kW}$. Stage 2 ended when the paper layer buried between the 20 - and $25 \mathrm{-cm}$ depth was consumed.

Stage 3 was designed to provide a complete test of the upgraded engineering-scale unit, the new power system, the water spray system, the positive pressure electrode seals, and the lightweight ceramic bead layer. Experience gained from the powered operation of phases 1 and 2 was incorporated into stage 3 to demonstrate the ease of operation for the three-phase. three-electrode power system. As with stage 2, the 75 kVA transformer was switched out of the circuit at the beginning of the test to provide for a higher voltage level during start-up.

Figure 5.4 illustrates the current and voltage profile for A-phase during stage 3 . According to the figure, the three-phase, three-electrode power system operated smoothly during the test stage. At $4 \mathrm{~h}$ into the test. fuses on one of the variacs failed. The cause of failure is unknown since the electrodes were not being moved at the time. Because this engineering-scale system is not representative of a field scale power supply, detailed efforts to identify the cause were not performed. Approximately $6.5 \mathrm{~h}$ into the test. the $75 \mathrm{kVA}$ transformer was reconnected into the circuit to provide a higher current limit. The periodic voltage and current "drops" illustrated in Figure 5.4 correspond to intervals during which the electrodes were fed into the melt by the pneumatic feed system. This procedure of lowering the power leveis before use of the electrode feed system was adopted after it was determined that increased current loads resulted from the added surface area of the fed electrodes.

Figure 5.5 illustrates the total power input as a function of time for stage 3. The desired power level of $30 \mathrm{~kW}$ was achieved early in the test (approximately $2.5 \mathrm{~h}$ ) and was maintained throughout the test. Downtime 


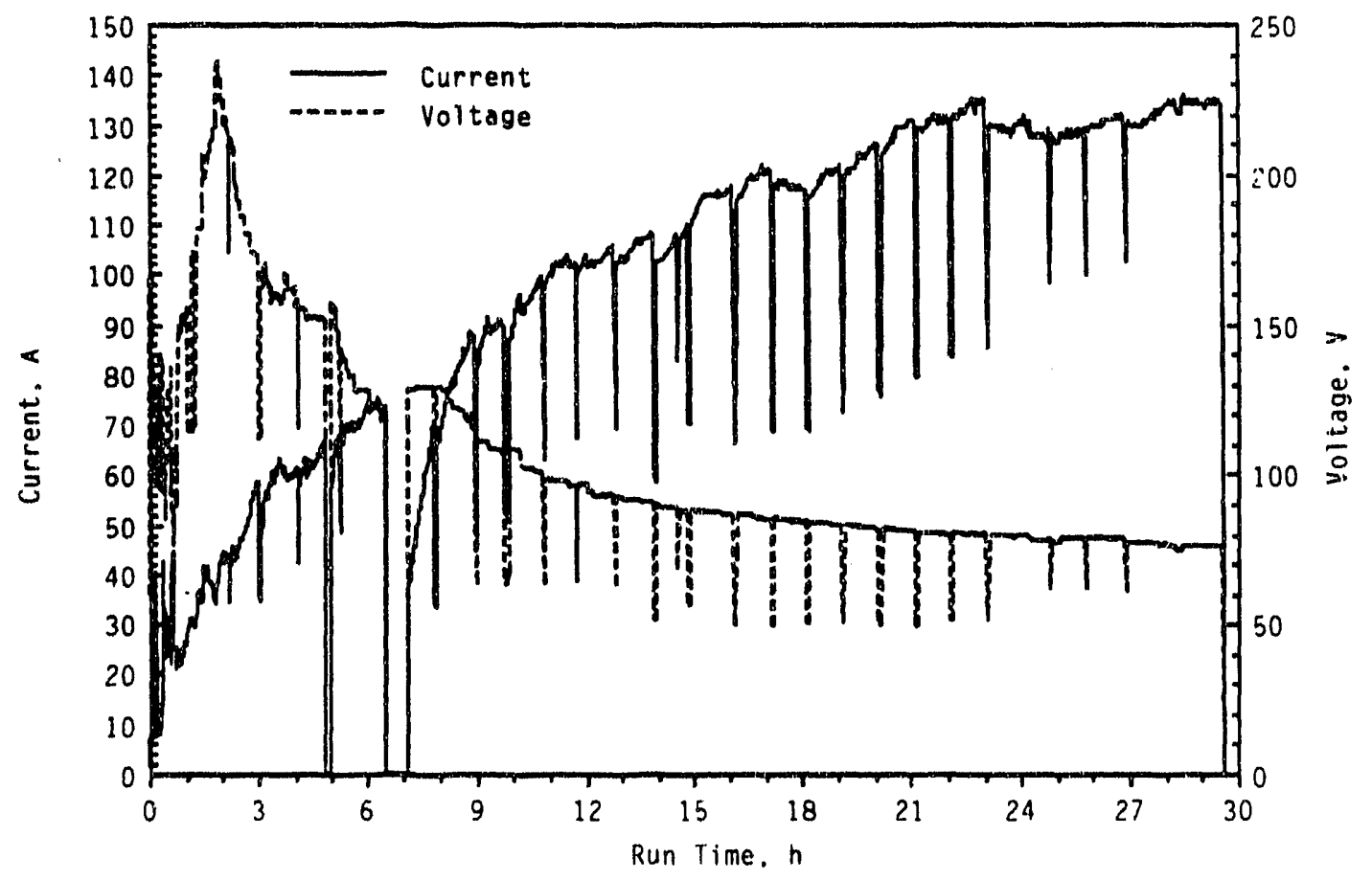

EIGURE 5.4. A-Phase Current and Voltage Profile - Stage 3. Voltage and current drops correspond to periods of manual electrode feeding.

during phase 3 was due to a blown fuse and the need to reconnect the $75 \mathrm{kVA}$ transformer. As with the current and voltage profiles, the power level "drops" correspond to periods when the electrodes wera fed into the ISV melt.

Integration of the total power profile over the duration of the stage 3 results in the total energy consumed during the stage. The total energy used was $810 \mathrm{kWh}$. which produced a block of approximately $830 \mathrm{~kg}$. The smooth opera. tion of the three-phase, three-electrode power system and the successful creation of an ISV block illustrate the applicability of the new power supply system for the ISV technology.

\subsection{WATER SPRAY SYSTEM PEREORMANCE}

A total of nine different trials of the water spray system were conducted in the off-gas containment hood: three during stage 2 and six during 


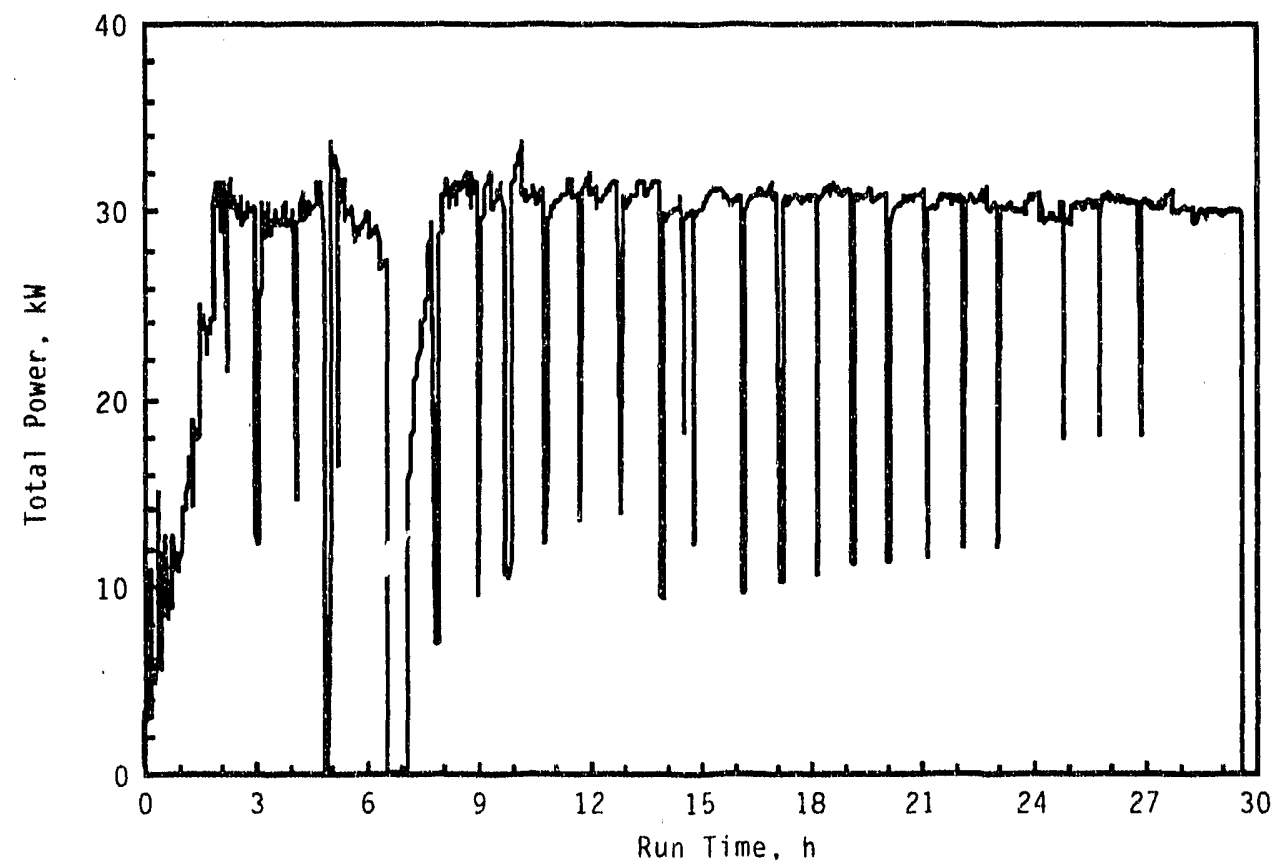

EIGURE 5.5. Total Power Profile - Stage 3. Power level drops correspond to periods of manual electrode feeding.

stage 3. The length of the water spray trials ranged between 2 and $25 \mathrm{~s}$. Figure 5.6 illustrates the pressure and temperature responses in the off-gas hood for two 10-s trials. During the trials illustrated in Figure 5.6, the vacuum in the off-gas hood increased from a nominal $1.6 \mathrm{~cm}$ w.c. to about $2.3 \mathrm{~cm} \mathrm{w.C.} \mathrm{in} \mathrm{approximately} 1.5 \mathrm{~s}$ (in Figure 5.6 minor time increments equal $6 \mathrm{~s})$. In addition, the temperature of the off gas exiting the container decreased almost $1.5^{\circ} \mathrm{C}$ for both trials $\left(\approx 126.5^{\circ} \mathrm{C}\right.$ to $\left.\approx 125^{\circ} \mathrm{C}\right)$. The results of the water spray system trials, in terms of reproducibility and the rapid response of the hood vacuum change. support the premise that energy transferred from the off gas via vaporization leads to an overall temperature decrease.

In addition to the pressure and temperature responses in the off-gas hood. Figure 5.6 also shows a rebound in the hood pressure to a lower vacuum after the water spray was discontinued. This rebound was due to the incomplete vaporization of water droplets in the off-gas hood plenum (thus not 


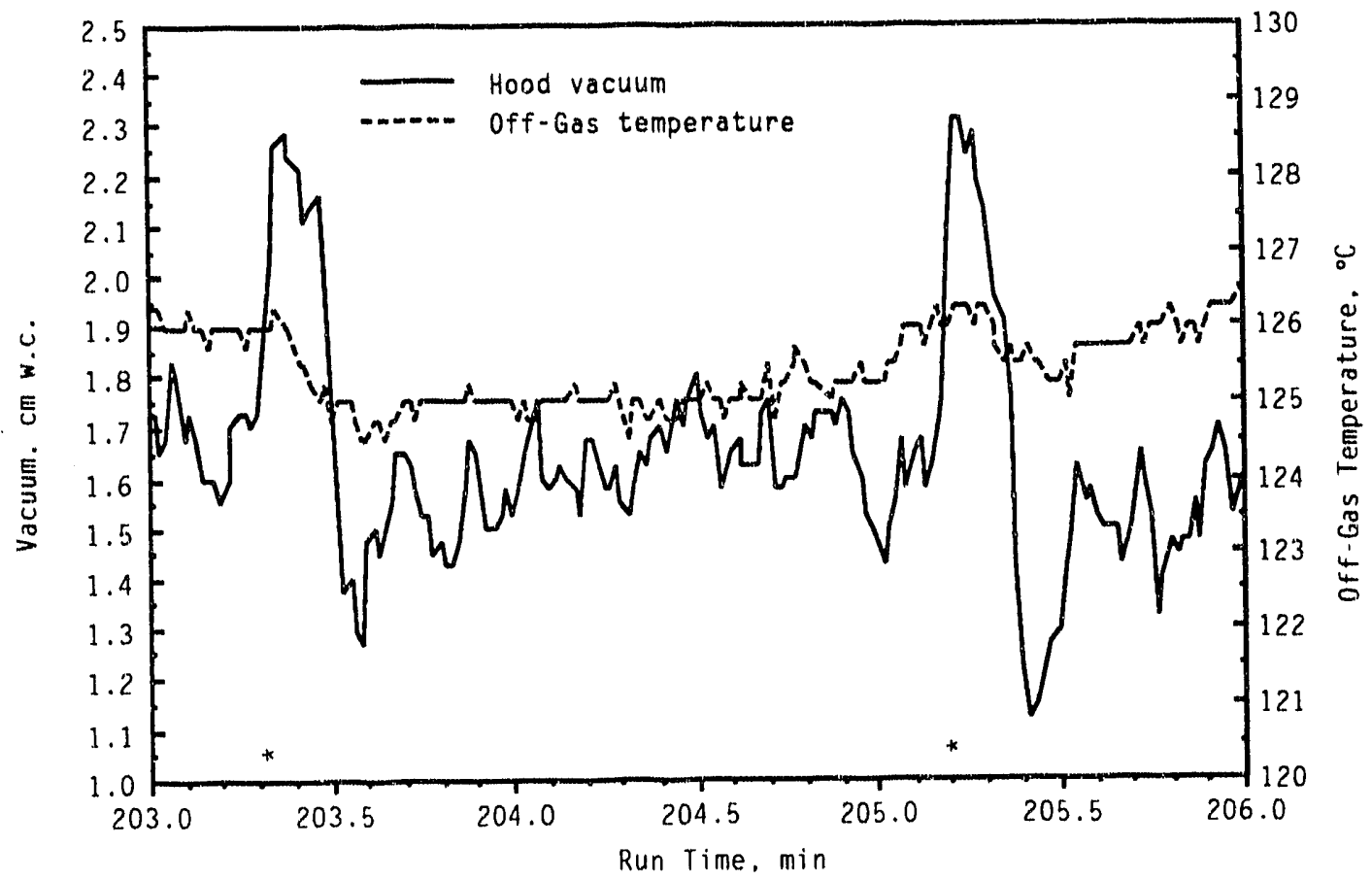

EIGURE 5.6. Pressure and Temperature Response for Two 10-s Water Spray System Trials. Start of trial denoted by $(*)$. Each time increment equals $6 \mathrm{~s}$.

providing the beneficial off-gas cooling) and the subsequent contact of the droplets with a hot surface (e.g.. the surface of the ceramic bead layer). (a) As will be discussed, the observed off-gas temperature decrease was smaller than predicted. which supports the hypothesis that the water added to the system was incompletely vaporized in the off-gas plenum.

The test results of the water spray system qualitatively met the predictions based on the theoretical assumptions and calculations discussed in Appendix A (i.e.. a decrease in temperature and pressure in the off-gas hood resulting from the addition of water). The following discussion will quantitatively illustrate how well the water spray system test results compared to predicted final values based on theoretical assumptions and calculations. As

(a) The water droplets contacting the hot surface vaporize by removing heat from the surface and do not remove energy from the off gas. As a consequence, the overall decrease in the off-gas temperature is insufficient to compensate for the expanding volume of the vaporized water. thereby leading to a rebound in the pressure. 
the following discussion will show, the actual temperature decrease in the hood was less than predicted $\left(\approx 5^{\circ} \mathrm{C}\right.$ less) due to the small temperature driving force for vaporization $\left(\approx 26^{\circ} \mathrm{C}\right)$. The factor believed to be responsible for the difference in calculated and observed off-gas temperature is incomplete transfer of energy from the gases in the hood to the added water. In other words. only a fraction of the added water was vaporized through the transfer of energy from the plenum gases: the remaining water vaporized after contacting a hot surface (e.g.. the surface of the ceramic bead layer), which did not lead to a temperature decrease in the hood (this phenomenon was observed during the water spray trials). The cause of this incomplete transfer of energy is the small driving force for energy transfer. approximately $26.5^{\circ} \mathrm{C}\left(126.5^{\circ} \mathrm{C}\right.$ minus $100^{\circ} \mathrm{C}$ ). This problem is not anticipated for field-scale ISV applications where the driving force is at least $200^{\circ} \mathrm{C}$ (normal operating off-gas tempera. tures are approximately $300^{\circ} \mathrm{C}$ ) and higher during a transient event.

PNL's upgraded engineering-scale ISV unit has a plenum volume of $3.58 \mathrm{~m}^{3}$ (container plenum plus expansion tank volume). For a hood pressure of $101.17 \mathrm{kPa}(-1.6 \mathrm{~cm} \mathrm{W.C.})$ and a temperature of $399.5 \mathrm{~K}$, the number of moles in the plenum is given by use of the ideal gas law. PV $=n R T$ or $n-P V / R T$, and results in 109.05 moles. According to Figure 5.6, the initiation of the water spray increased the vacuum to $2.3 \mathrm{~cm} \mathrm{w.c.} \mathrm{(101.10} \mathrm{kPa)} \mathrm{and} \mathrm{decreased} \mathrm{the} \mathrm{tem-}$ perature to $398 \mathrm{~K}$. Use of the ideal gas law shows that the number of moles present in the hood plenum at these conditions is 109.38 moles, indicating that 0.33 moles ( 109.38 moles minus 109.05 moles) of water was added. This agrees with the number of moles calculated for a $10-\mathrm{s}$ water spray trial:

moles water $-(10 \mathrm{~s})(37 \mathrm{~mL} / \mathrm{min})(1 \mathrm{~min} / 60 \mathrm{~s})(1 \mathrm{~g} / \mathrm{mL})(1 \mathrm{~mole} / 18 \mathrm{~g})$

or moles of water added -0.34 moles.

The fact that the number of moles of water added to the system agrees with that calculated for the final hood conditions is encouraging because it supports the conclusion that all of the moles of added water evaporated. The calculations for the water spray system were further assessed by determining if the actual and predicted final hood conditions agreed. The final temperature in the off-gas hood can be determined through the an energy balance for the system: 


$$
K E(\text { final) }=K E(\text { gas })+K E(\text { water })+x \lambda \text { (water) }
$$

or

$\frac{5 N k T_{\text {final }}(109.38)}{2}-\frac{5 \mathrm{Nk}(399.5)(109.05)}{2}+\frac{(0.34(6 \mathrm{Nk})(373)}{2}+0.34\left(-4.07 \times 10^{4}\right)$

which reduces to $T_{\text {final }}=393.6 \mathrm{~K}$ or $120.6^{\circ} \mathrm{C}$. This predicted final temperature is $5^{\circ} \mathrm{C}$ lower than that actually observed in the off-gas hood $\left(125^{\circ} \mathrm{C}\right)$.

\subsection{INSULATIVE CERAMIC BEAD LAYER PERFORMANCE}

A 3- to 6-cm-thick layer of lightweight ceramic beads was used for all three powered operation phases. Figure 5.7 illustrates the general configuration used for the ceramic bead layer. Kaowool covered the expected perimeter of the ISV melt, and the ceramic beads were placed between the electrodes

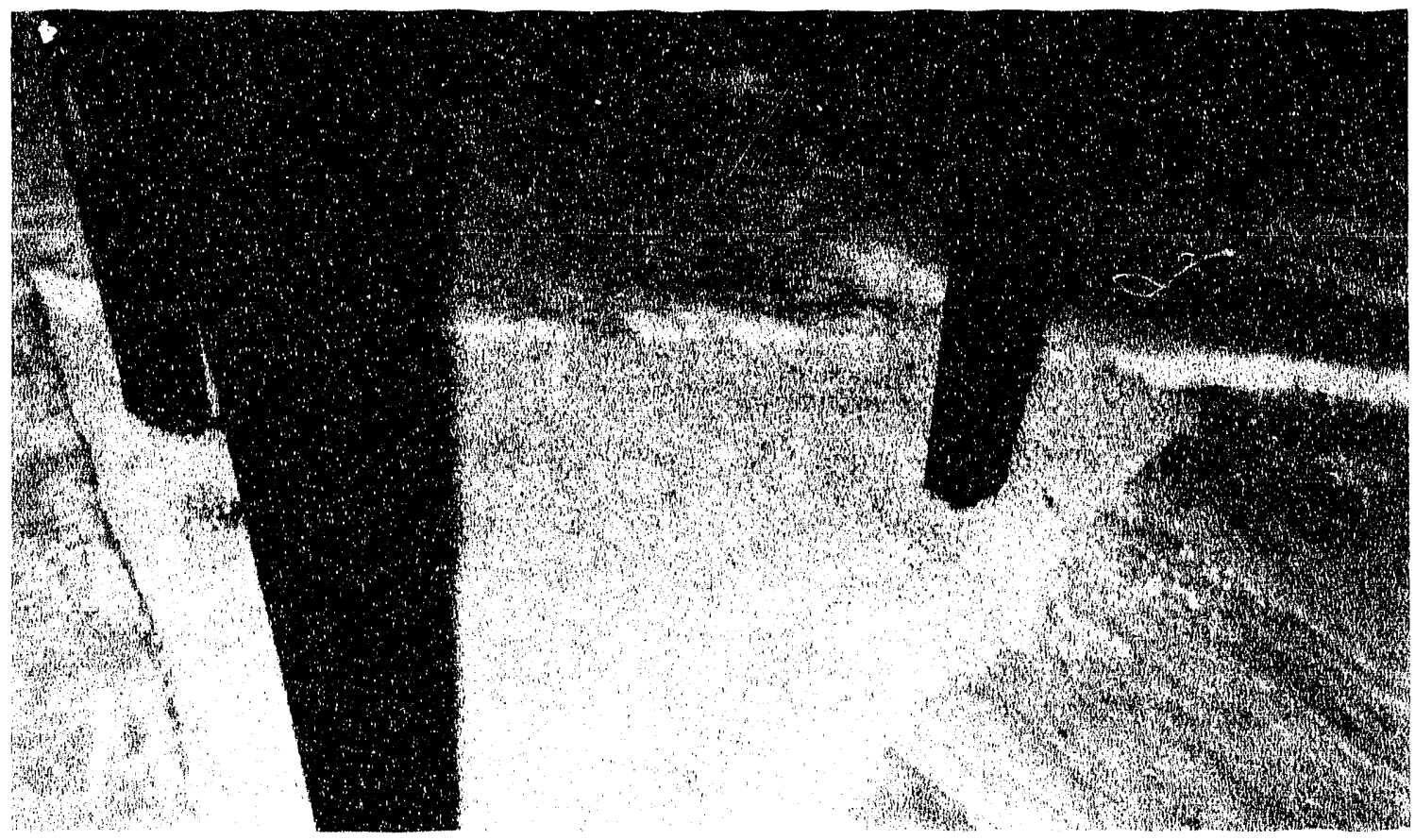

EIGURE 5.7. Ceramic Bead Configuration Before Start-Up 
over the area to be vitrified. Figure 5.8 illustrates the early phases of a powered stage and shows molten soil beginning to form around two of the electrodes. The glow emitted by the lightweight ceramic beads allowed for observation of the forming molten soil region.

Figure 5.9 shows the ceramic bead layer over a fully established ISV melt. The visible flaring around one of the electrodes was due to the combustion of gases emanating from the ISV melt. Similar. smaller flares were observed at various locations through the ceramic bead surface during testing. These smaller flares indicated that the ceramic bead lay.r allowed gases to easily escape.

Before removal of the vitrified block from the engineering-scale unit, a significant fraction of the beads that were originaliy placed over the insulating soil were retrieved. During this retrieval process, it was noted that the beads remained separate from one another and free of vitrified soil

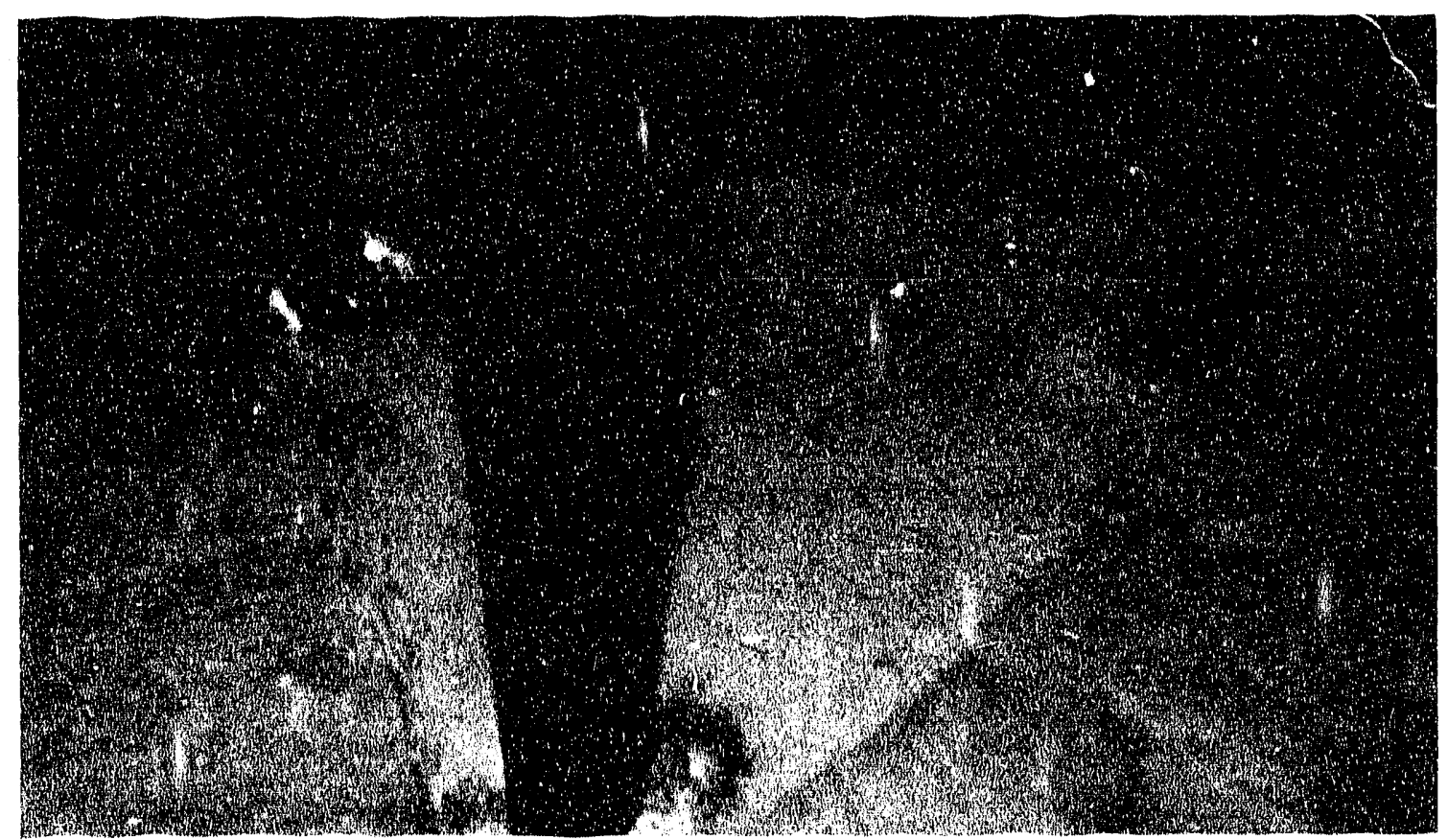

FIGURE 5.8. Early Powered Stage with Molten Soil Showing Through the Beads 


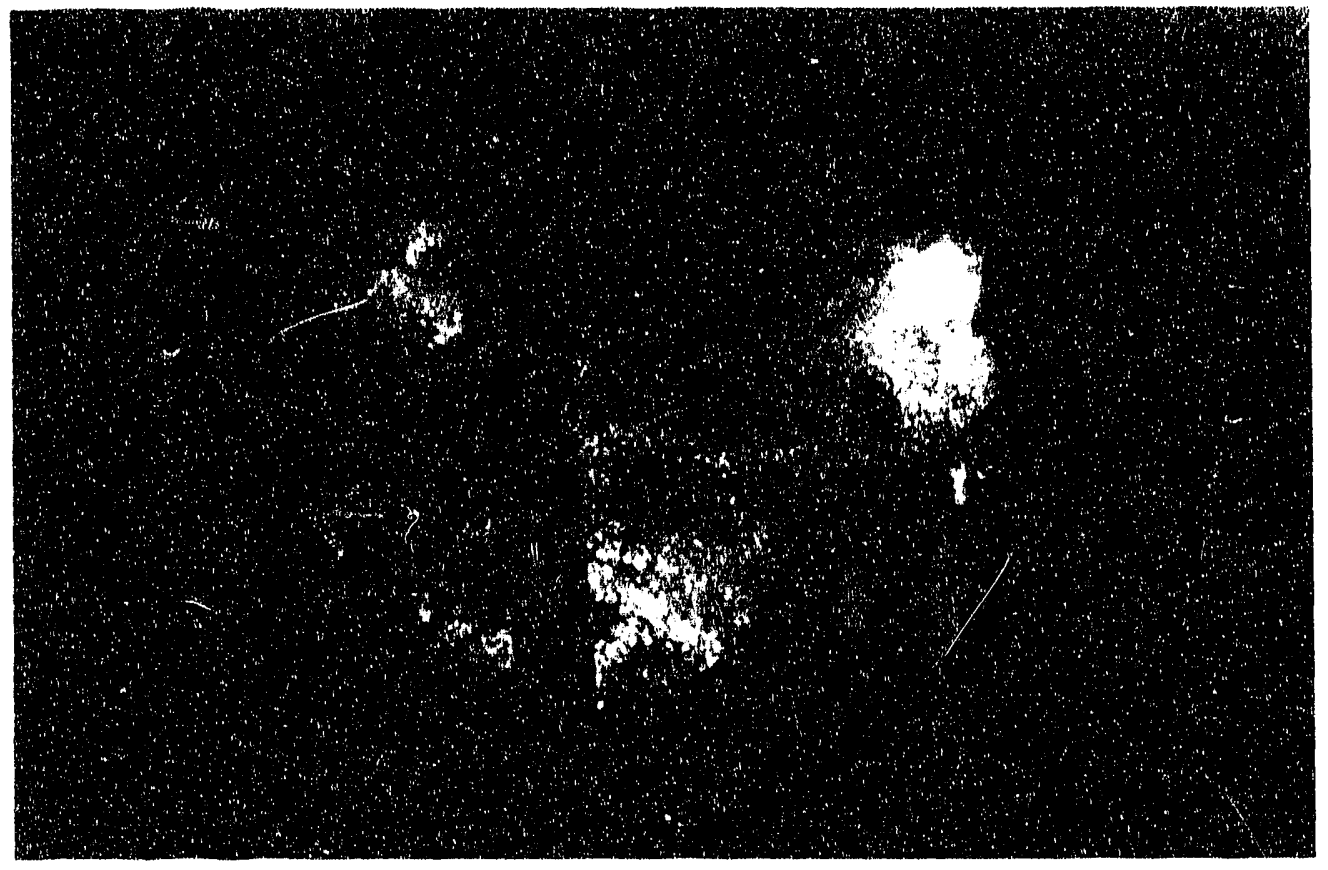

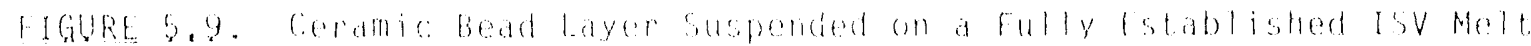

product. Inese characteristics support lhe conclusion that bubbling of the meit surtace was oither absent or loss dymamis than normally observed. If bubbling had occured. Iho molten soil would have been oxpected to flow into a sgafficant portion of ho bead void space and callse an dgalomeration of the beads. Figure b.jo ilhotrates the top surface of the stage a lsv block after removal from the engineerimg scale mit. The remaining bead layer was at ached directly to the vitrified soil product.

S.A POSITIVE PRESSURE RLECTROUE STAL PEREORMANCE

A single set of positive prossure aloctrole seals was lased for all three: powerod operational stages. lables.l illustrates the air inlet flow rates required to maintain a 20.68 kpag set point pressure within the electrode seal chamber. The required air inlet flow rate in lable b.l is the lotal flow rate required for a il three positive pressure electrode seals. This flow rate remained stable or improved during each of the three stages. indicating that the fabric soals within each electrode seal assembly were relatively unaf fected sy the tamperature within the liv unit and by the repeated electrode 


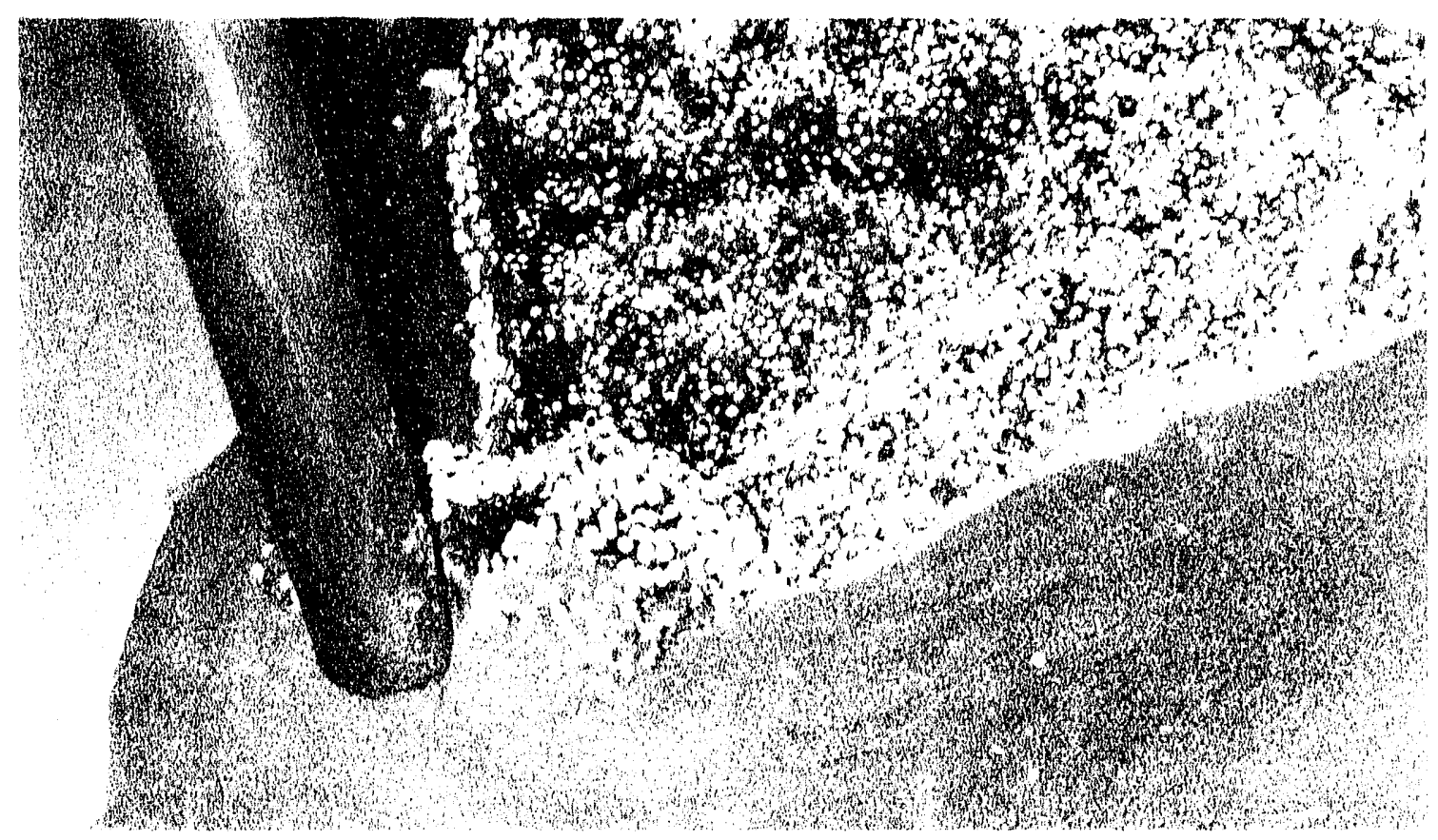

FIGURE 5.10. Surface of ISV Product After Cooldown and Excavation

movement. If the seal had deteriorated substantially, the required air flow rate would have increased; no such increase was observed during testing.

Based on physical inspection of the positive pressure electrode seals, the fabric in contact with the electrodes was beginning to exhibit minor signs of wear due to the electrode movement. Normal wear was most pronounced on the uncoated high temperature fabric at the base of the seal, which was designed to protect the coated fabric seals from molten glass splatter. In addition. the coated fabric seals. which provided the wiping action on ine electrodes. were free of any signs of thermal degradation. For field-scale applications, the electrode seals will be periodically changed prior to each setting to minimize the amount of normal wear the electrode seals will experience.

Implementation of the positive pressure seal system on field-scale units is planned to eliminate the potential for untreated escape of gases and particulate around the electrode insertion points into the off-gas containment hood. 
IABLE 5.1. Positive Pressure Electrode Seal Inlet Air Flow Rates. The inlet flow rates were manually adjusted to maintain a seal chamber pressure of $20.68 \mathrm{kPag}$.

\begin{tabular}{|c|c|c|c|}
\hline Stage & Date & Bun Timesh & Required Flow Bate. $\mathrm{m}^{3} / \mathrm{min}$ \\
\hline 1 & $9 / 3 / 91$ & $\begin{array}{l}12: 15 \\
13: 30 \\
15: 30 \\
18: 00\end{array}$ & $\begin{array}{l}0.014 \\
0.014 \\
0.014 \\
0.014\end{array}$ \\
\hline 2 & $9 / 4 / 91$ & $\begin{array}{r}8: 25 \\
9: 23 \\
11: 00 \\
15: 55\end{array}$ & $\begin{array}{l}0.017 \\
0.016 \\
0.013 \\
0.013\end{array}$ \\
\hline 3 & $9 / 11 / 91$ & $\begin{array}{r}8: 49 \\
9: 54 \\
11: 16 \\
12: 36 \\
14: 11\end{array}$ & $\begin{array}{l}0.018 \\
0.017 \\
0.019 \\
0.017 \\
0.016\end{array}$ \\
\hline
\end{tabular}




\subsection{REFERENCES}

Buelt, J. L., C. L. Timmerman, K. H. Oma, V. F. Fitzpiatrick, and J. G. Carter. 1987. In situ vitrification of Transuranic Waste: An Updated Systems Evaluation and Applications Assersment. PNL-4800 suppl. 1. Pacific Northwest Laboratory, Richland, Washington.

Callow, R. A., L. E. Thompson, J. R. Weidner, C. A. Lcehr, B. P. McGrail, and S. 0 . Bates. 1991. In Situ Vitrification Application to Buried Waste: Einal Report of Intermeniate Field Iests at Idahe National Engineering Laberatory. EGG-WTD-9807. EG\&G Idaho. InC., Idaho Falls, Idaho.

Elgard. 0. 1. 1982. Electric Eneray System Theory. McGraw-Hill. New York.

Leardini. T., and M. Cadeddu. 1961. "Caverns as Nuclear Power Reactor Containers: Further Experimentai Results." Energid Nucleare 8(2):93-98.

Liwchitz-Garik. M.. and C. C. Whipple. 1961. Alternating Current Machines. D. Von Nostrand, New York.

Massachusetts Institute of Technology. Department of Electrical Engineering. 1950. Maanetic Circuits and Iransformers. John Wiley. New York.

Westinghouse Electric Corporation. 1950. Electrical Iransmission and Distribution Reference Book. 
APPENDIX A

WAIER SPRAY SYSTEM CALCULATIONS AND ASSUMPTIONS 
An evaluation of the water spray system is presented here. Normal pilotscale off-gas hood operating conditions and constants used for water spray calculations are listed in Table A.1. For the hypothetical case, 12 moles of $1200^{\circ} \mathrm{C}$ steam enter the off-gas hood from the ISV melt, causing pressurization of the hood and some heating of the gases present in the plenum. First, the increases in the temperature and pressure of the off-gas hood caused by the introduction of the steam are estimated. Then, an estimation of the number of moles of water necessary to reestablish the vacuum within the off-gas hood is performed.

The kinetic energy of a mole of gas is a function of temperature as shown in Eq. (1):

$$
K E=\frac{n_{f} N k T}{2}
$$

where $K E$ is kinetic energy (erg/mole) and $T$ is absolute temperature ( $K)$.

IABLEA.1. Numerical Values for Water Spray System Calculations: IntermediateScale Off-Gas Hood Conditions and Constants.(a)

Normal Intermediate-Scale off-Gas Hood Operating Conditions

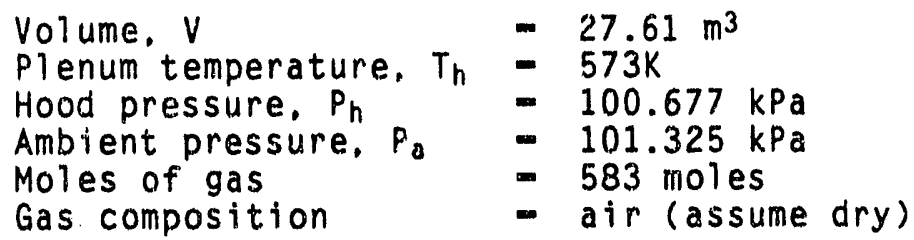

(a) Perry and Green (1984). 
Assuming the total kinetic energy (translational, rotational, and vibrational) is conserved: KE (final) - KE ( $p$ lenum gases) + KE ( 12 moles $1200^{\circ} \mathrm{C}$ steam). Using Eq. (1) leads to

$$
\frac{5 N k T_{f}(583+12)}{2} \approx \frac{5 N k(573)(583)}{2}+\frac{6 N k(1473)(12)}{2}
$$

where $T_{f}$ is the final temperature in the off-gas hood after the addition of the 12 moles of $1200^{\circ} \mathrm{C}$ steam. To simplify the calculation. note the assumption that the final 595 moles of gas in the hood can be considered diatomic (predominate gas is air). Rearranging and solving for $T_{f}$ leads to a final temperature in the off-gas hood of 597K. Using the ideal gas law $(P V=n R T)$, the resulting hood pressure would be $106.98 \mathrm{kPa}$ or $58.7 \mathrm{~cm} \mathrm{W.C..}$ gauge.

In summary, an instantaneous 12 -gmol release of steam at $1200^{\circ} \mathrm{C}$ from the ISV melt into the off-gas containment hood would elevate the temperature of the off-gas hood plenum to $597 \mathrm{~K}$ and result in a positive pressure within the off-gas hood of $58.7 \mathrm{~cm} \mathrm{W.C.} \mathrm{(106.98} \mathrm{kPa,} \mathrm{absolute).}$

We now want to estimate the number of moles of water that would be required to quench the off-gas hood gas. effectively cooling it and lawering the pressure within the hood to the original value of $100.677 \mathrm{kPa}(-6.6 \mathrm{~cm}$ w.c.. gauge). Assume $x$ moles of water will be added to the 59 . moles of gas present in the off-gas hood, giving a total of $y-x+595$ moles. The final temperature in the off-gas hood will be related to the total number of moles. $y$, by the ideal gas law (PV - YRT or $T-P V / Y R$ ):

$$
T_{\text {final }}=\frac{(100.677 \mathrm{~Pa})\left(27.61 \mathrm{~m}^{3}\right)}{(y \text { moles })\left(8.314 \mathrm{~m}^{3} \mathrm{~Pa} / \text { mole K }\right)}
$$

or $T_{\text {final }}-334,339 / y$ (degrees $K$ ).

Assuming that the hood gas can still be considered predominately diatomic, even though $x$ moles of water (triatom;i) are added, the following 
energy balance equation can be used to solve for $y$ (the total number of moles after quenching)(o):

$$
\begin{gathered}
\text { KE (final) }- \text { KE (gas) }+ \text { KE (water) }+x \lambda \text { (water) } \\
\text { or } \\
\frac{5 N k(334.339) y}{2 y}-\frac{5 N k(597)(595)}{2}+\frac{(y-595)(6 N k)(373)}{2}+(y-595)\left(-4.07 \times 10^{4}\right)
\end{gathered}
$$

Solving for $y$ results in a final number of moles in the off-gas hood of 608.8 moles. Using the relationship that $T_{\text {final }}-334,339 / y$ leads to a final temperature in the off-gas hood of $549.1 \mathrm{~K}$. Also, since the initial number of moles in the off-gas hood before addition of the water was 595 moles, the number of moles of water required to reduce the temperature in the off-gas hood from $597 \mathrm{~K}$ to $549.1 \mathrm{~K}$ is 13.9 moles or $250.2 \mathrm{~g}$ (608.9 - 595 moles).

The kinetic theory-based calculations predict that 595 moles of gases in the off-gas hood would be cooled from $597 \mathrm{~K}$ to $549.1 \mathrm{~K}$. a temperature difference of $47.9 \mathrm{~K}$, by the vaporization of 13.9 moles $(250.2 \mathrm{~g})$ of water. If this calculation is valid, then the heat gained by the water spray for vaporization should equal the heat lost by the gases present in the offrgas hood. Assuming gas quenching to be a constant-pressure process. the heat lost by the gases in the off-gas hood $(\Delta H)$ can be calculated by $\Delta H=m C_{p} \Delta T$, where $m$ is the mass of gases in the hood and $C_{p}$ is the heat capacity of air. Using a molecular weight for air of $29 \mathrm{~g} / \mathrm{mole}$ and a heat capacity for air of $1.01 \mathrm{~J} / \mathrm{g} \mathrm{K}$ (at $573 K$ ) leads to:

$\Delta H=(595 \mathrm{moles})(29 \mathrm{~g} / \mathrm{mole})(1.01 \mathrm{~J} / \mathrm{g} \mathrm{K})(549.1 \mathrm{~K}-597 \mathrm{~K})$

and $\Delta H=-834.779 \mathrm{~J}$ or $-834.8 \mathrm{~kJ}$.

If the gas quenching process is constant-volume rather than constantpressure, then $C_{v}$. the constant volume heat capacity. would be used to calculate the change in energy. For air. $C_{v}$ can be calculated based on the specific heat ratio, $k$, which is defined as $k-C_{p} / C_{v}$. At $101.325 \mathrm{kPa}$, the specific heat ratio for air is 1.36 (Perry and Green 1984). Assuming a

(a) This calculation neglects the additional cooling that is achieved as the water added to the system is raised from its initial supply temperature to its vaporization temperature. 
constant-volume process, the change in internal energy. $U$, of the gases would be given by $\Delta U-m C_{v} \Delta T$. Comparison of this equation with that for a constantpressure process leads to:

$$
\Delta U-\Delta H C_{V} / C_{p}-\Delta H / K
$$

or $\Delta U=-613.8 \mathrm{~kJ}$. Therefore, based on actual heat-capacity data, rather than kinetic energy theory, the change in energy of the gases as the result of cooling would be in the range -613.8 to $-834.8 \mathrm{~kJ}$. The energy gained by the quenching-water should be within this range. The total heat gained by the water is equal to: $\Delta Q=m(\Delta K E+\lambda+\Delta u)$ where $Q$ is heat. The change in kinetic energy of water being raised in temperature from $373 \mathrm{~K}$ to $549.1 \mathrm{~K}$ (the final hood temperature) is given by Eq. (1):

$$
\Delta K E=\frac{6 N K(548.6-373)}{2}
$$

or $\Delta K E-4.38 \mathrm{~kJ} / \mathrm{mole}$. The change in internal energy of the added liquid water can be calculated using the relationship $\Delta U=C_{V} \Delta T$ (for liquids $C_{V} \approx$ $C_{p}$ ). Assuming an inlet water temperature of $293 \mathrm{~K}$, the change in internal energy is given by:

$$
\Delta u=(75.4 \mathrm{~J} / \text { mole K })(373 \mathrm{~K}-293 \mathrm{~K})
$$

or $\Delta u=6.03 \mathrm{~kJ} / \mathrm{mole}$. The total heat gained by the water is, therefore:

$$
\Delta Q-13.9 \mathrm{moles}(4.38 \mathrm{~kJ} / \mathrm{mole}+40.7 \mathrm{~kJ} / \mathrm{mole}+6.03 \mathrm{~kJ} / \mathrm{mole})
$$

or $\Delta 0=710 \mathrm{~kJ}$. The heat gained by the water is within the range of 613.8 to $834.8 \mathrm{~kJ}$ predicted by heat-capacity data. Therefore, the calculation checks within the range of uncertainty whether the cooling process is constantpressure or constant-volume. 


\section{REFERENCE}

Perry, R. H., and D. W. Green. 1984. Perry's Chemical Engineers' Handbook. 6th Edition. McGraw-Hill. New York. 


\section{DISTRIBUTION}

No. of

Copies

\section{OFESITE}

12 DOE/Office of Scientific and Technical Information

21 DOE Office of Environmental Restoration and Waste Management Trevion II Building 12800 Middlebrook Road Germantown. MD 20874 ATTN:W. W. Al exander

T. D. Anderson

J. E. Baublitz

D. L. Biancasino

J. 0. Boda

J. Coleman

S. P. Cowan

J. J. Fiore

C. W. Frank

K. O. Hain

J. M. Lankford

J. C. Lehr

S. C. Lein

J. E. Lytle

S. A. Mann

S. M. Prestwich

M. Shupe

C. H. Sink

L. H. Taylor

H. F. Walter

R. P. Whitfield

2 DOE Albuquerque Operations Office

P.O. Box 5400

Albuquerque. NM 87115

ATTN: P. A. Saxman

D. H. Bandy

W. Holman

DOE San Francisco Field

Office

1333 Broadway

Oakland. CA 94612
No. of

Copies

J. Haugen

DOE Chicago Field Office

9800 South Cass Avenue

Argonne, IL 60439

J. Hall

DOE Nevada Field Office

P.O. Box 98518

Las Vegas, NV 89193-8518

R. Tyler

DOE Rocky Flats Office

DOE Building 116

Golden, CO 80402-0928

S. Ketola

DOE West Valley Project

P.O. Box 191

West Valley. NY 14171

W. Fitch

DOE Idaho Operations Office

785 DOE Place

Idaho Falls, ID 83402

M. O'Rear

DOE Savannah River Operations Office

P.O. BOX A

Aiken. SC 29801

4 DOE Oak Ridge Office

P.0. Box 2001

Oak Ridge. TN 37831

ATTN: J. Moore (2)

J. Sweeney (2)

3 Battelle Memorial Institute

505 King Avenue

Columbuj, OH 43201

ATTN: W. A. Carbeiner

R. A. Nathan

Technical Library 
No. of

Copies

Jesse L. Yow, Jr.

Lawrence Livermore National Laboratory

7000 Easi Avenue

Livermore, CA 94550

M.A.H. Reimus

Los Alamos National

Laboratory

P. O. Box 1663

Los Alamos, NM 87545

J. Koger

Martin Marietta Energy

Systems

P.0. Box 2009

Oak Ridge, TN 37831-8097

P. T. Owen

Martin Marietta Energy

Systems

P.0. Box 2003

Oak Ridge, TN 37831-7256

8 Oak Ridge National Laboratory

P. D. BOX Y

Oak Ridge, TN 37830

ATTN: G. K. Jacobs (4)

M. Naney (2)

B. P. Spalding (2)

K. Nuhfer

Westinghouse Materials Co. of Ohio

P.0. Box 398704

Cincinnati, OH 45239-8704

5 Sandia Laboratories

P.0. Box 5800

Albuquerque, NM 87185

ATTN: $D$. Berry

R. Knowlton

J. Phelan

L. D. Tyler

Technical Library
No. of

Cepies

5

EG\&G Idaho

P.0. Box 1625

Idaho Falls. ID 83415

ATTN: J. L. McAnnaly

S. K. Merrill

D. F. Nickelson

R. L. Norl and

R. R. Stiger

L. Rogers

EG\&G Energy Measurements, Inc.

P.0. Box 1912. MS RSL-11

Las Vegas, NV 89125

B. Haas

Ames Laboratory

7 Spedding $\mathrm{Hall}$

Iowa State University

Ames, IA 50011

6 Westinghouse Savannah River Company

P. 0 . Box 616

Aiken, SC 29801

ATTN: J. S. Haselow

C. M. Jantzen

M. J. Plodinec

J. F. Sproull

J. L. Steele

T. Walton

J. M. Pope

West Valley Nuclear

Services Co.

P.0. Box 191

West Valley. NY 14171 
No. of

Copies

4 Geosafe Corporation 2000 Logston Boulevard Richland. WA 99352

ATTN: C. L. Timmerman (2)

B. E. Campbell

J. E. Hanson

\section{ONSITE}

13 DOE Richland Field Office

E. A. Bracken, A6-95

K. W. Bracken, A5-22

R. P. Carter. A5-21

P. K. Clark, $A 6-80$

P. F. Dunigan. A6-95

J. K. Erickson, A5-19

R. D. Freeburg, A5-19

M. J. Furman, $A 6-80$

R. E. Gerton, $A 6-80$

J. D. Goodenough. A5-22

J. M. Hennig, A5-21

R. D. Izatt, $A 6-95$

J. J. Sutey, A5-90

13 Westinghouse Hanford Companx
W. C. Alaconis, L4-92
H. Babad, B3-68
J. D. Berger, $\mathrm{LO}-18$
J. W. Cammann, H4-54
K. R. Fecht, H4-56
R. E. Lerch, B2-35
H. E. McGuire, B2-35
J. W. Shade, R4-03
D. A. Turner, R1-10
D. D. Wodrich, RI-48
R. D. Wojtasek, B2-15
B. A. Wolfe, L5-61
R. L. Gilchrist, L5-63

No. of

Copies

30

Pacific Northwest Laboratery

L. Ballou, P7-18

W. F. Bonner, P7-44

J. L. Buelt, P7-41

H. C. Burkholder, P7-41

W. 0. Heath, P7-41

W. L. Kuhn, PB-38

P. A. Lowery, K7-15

J. Luey, P7-34 (7)

J. L. MCElroy, P7-46

M. E. Peterson, P7-41

T. D. Powe 11, P7-34

R. L. Richardson, P7-41

S. C. Slate, K1-25

S. L. Stein, K1-25

L. E. Thompson, P7-34

J. S. Tixier, P7-34

C. L. Widrig, P7-34

S. L. Woos ley, P7-34

Publishing Coordination

Technical Report Files (5) 

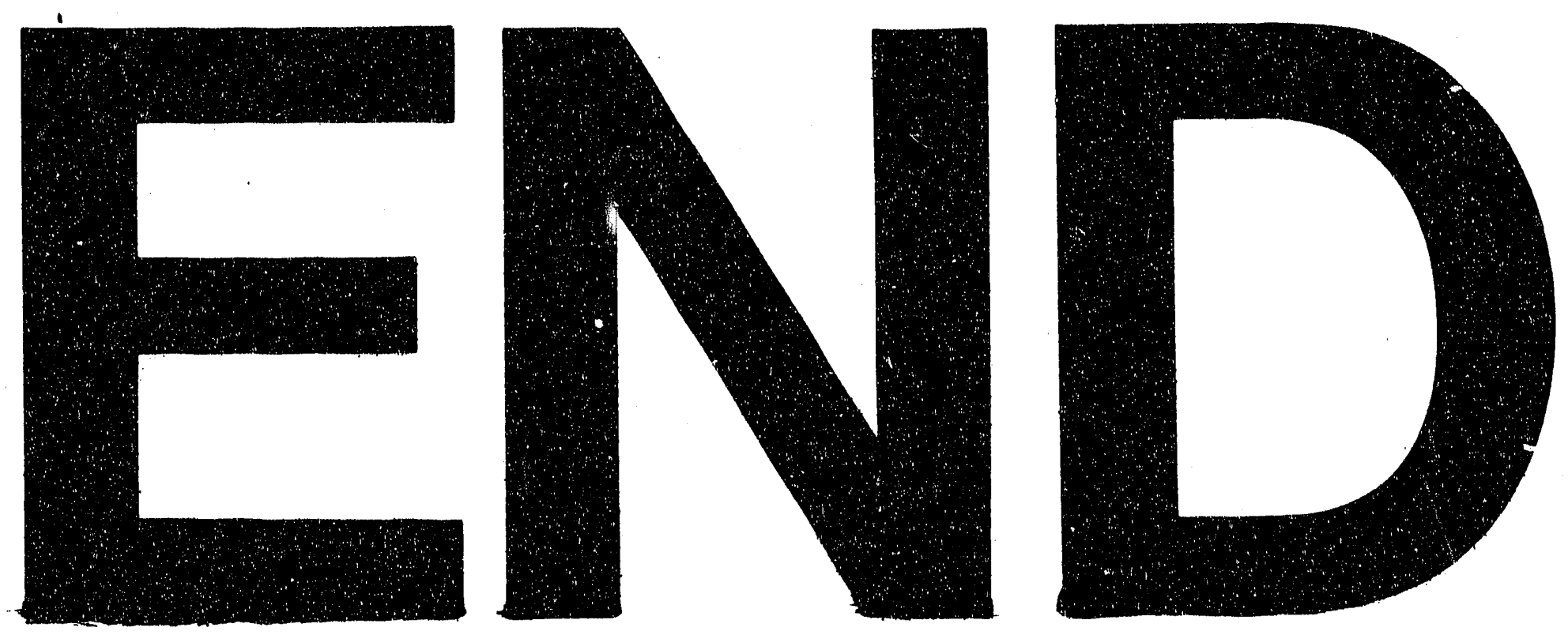

-
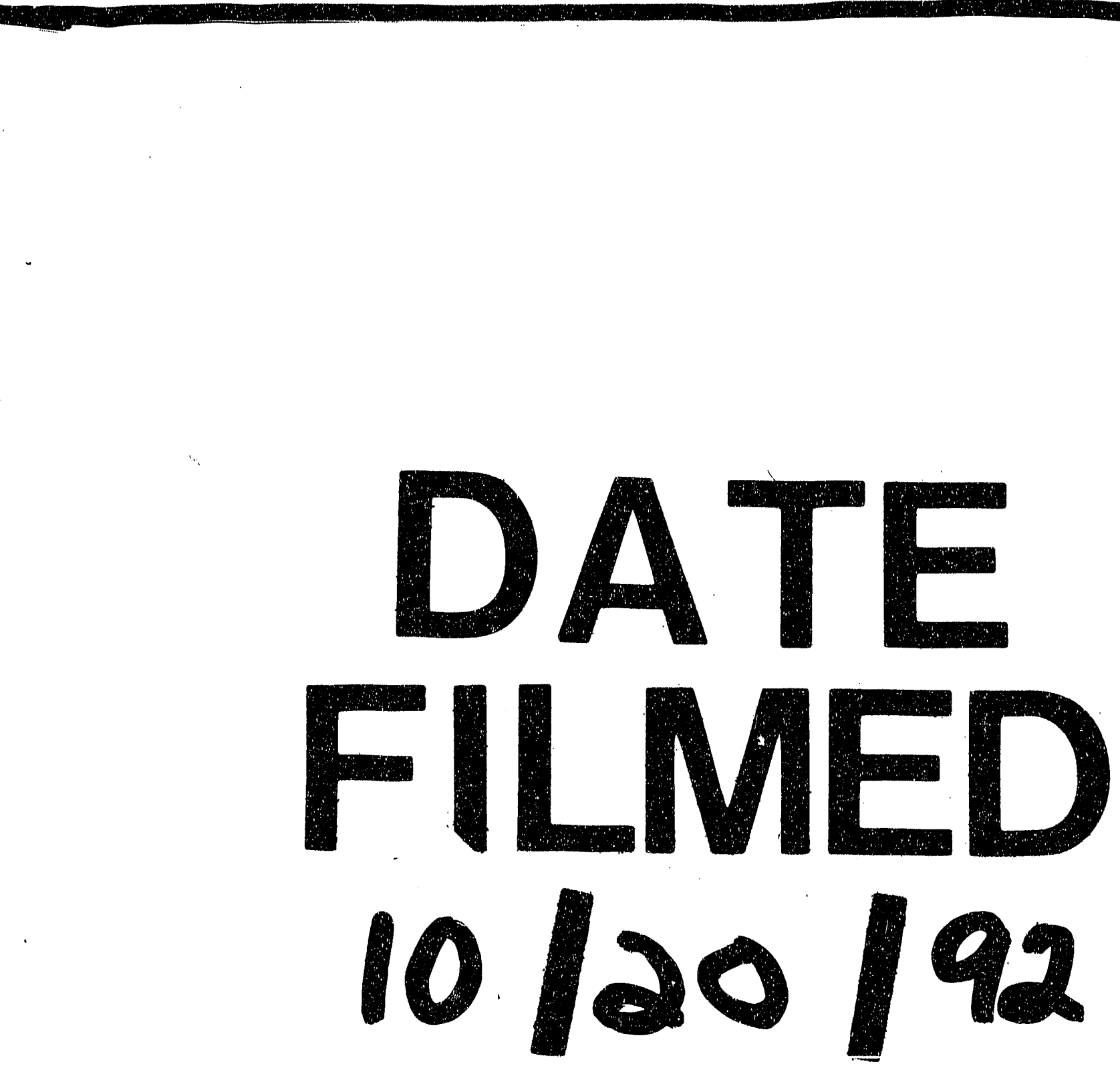

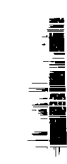


